\title{
Impact of Acute and Persistent Excitation of Prelimbic Pyramidal Neurons on Motor Activity and Trace Fear Learning
}

\author{
Timothy R. Rose, ${ }^{1 *}{ }^{\circledR}$ Ezequiel Marron Fernandez de Velasco, ${ }^{2 *}$ Baovi N. Vo, ${ }^{1}$ Megan E. Tipps, ${ }^{2}$ and \\ - Kevin Wickman ${ }^{2}$ \\ ${ }^{1}$ Graduate Program in Pharmacology, and ${ }^{2}$ Department of Pharmacology, University of Minnesota, Minneapolis, Minnesota 55455
}

Drug-induced neuroadaptations in the mPFC have been implicated in addictive behaviors. Repeated cocaine exposure has been shown to increase pyramidal neuron excitability in the prelimbic (PL) region of the mouse mPFC, an adaptation attributable to a suppression of $\mathrm{G}$ protein-gated inwardly rectifying $\mathrm{K}^{+}$(GIRK) channel activity. After establishing that this neuroadaptation is not seen in adjacent GABA neurons, we used viral GIRK channel ablation and complementary chemogenetic approaches to selectively enhance PL pyramidal neuron excitability in adult mice, to evaluate the impact of this form of plasticity on PL-dependent behaviors. GIRK channel ablation decreased somatodendritic $G_{A B A}$ receptor-dependent signaling and rheobase in PL pyramidal neurons. This manipulation also enhanced the motor-stimulatory effect of cocaine but did not impact baseline activity or trace fear learning. In contrast, selective chemogenetic excitation of PL pyramidal neurons, or chemogenetic inhibition of PL GABA neurons, increased baseline and cocaine-induced activity and disrupted trace fear learning. These effects were mirrored in male mice by selective excitation of PL pyramidal neurons projecting to the VTA, but not NAc or BLA. Collectively, these data show that manipulations enhancing the excitability of PL pyramidal neurons, and specifically those projecting to the VTA, recapitulate behavioral hallmarks of repeated cocaine exposure in mice.

Key words: chemogenetics; cocaine; fear conditioning; GIRK; motor activity.

Significance Statement

Prolonged exposure to drugs of abuse triggers neuroadaptations that promote core features of addiction. Understanding these neuroadaptations and their implications may suggest interventions capable of preventing or treating addiction. While previous work showed that repeated cocaine exposure increased the excitability of pyramidal neurons in the prelimbic cortex (PL), the behavioral implications of this neuroadaptation remained unclear. Here, we used neuron-specific manipulations to evaluate the impact of increased PL pyramidal neuron excitability on PL-dependent behaviors. Acute or persistent excitation of PL pyramidal neurons potentiated cocaine-induced motor activity and disrupted trace fear conditioning, effects replicated by selective excitation of the PL projection to the VTA. Our work suggests that hyperexcitability of this projection drives key behavioral hallmarks of addiction.

Received 0ct. 8, 2020; revised Dec. 11, 2020; accepted Dec. 16, 2020.

Author contributions: K.W., T.R.R., E.M.F.d.V., and M.E.T. designed research; K.W., T.R.R., E.M.F.d.V., B.N.V., and M.E.T. analyzed data; K.W., T.R.R., E.M.F.d.V., B.N.V., and M.E.T. edited the paper; T.R.R., E.M.F.d.V., B.N.V., and M.E.T. performed research; T.R.R. wrote the first draft of the paper; E.M.F.d.V. contributed unpublished reagents/analytic tools.

${ }^{*}$ T.R.R. and E.M.F.d.V. contributed equally to this work.

This work was supported by National Institutes of Health Grants MH061933, DA034696, and AA027544 to K.W., AA025978 to M.E.T., and DA007234 to T.R.R.; Wallin Neuroscience Discovery Fund Award to K.W.; and University of Minnesota Doctoral Dissertation Fellowship to B.N.V. We thank Zhilian Xia, Nicholas Carlblom, Hannah Oberle, and Mehrsa Zahiremami for exceptional care of the mouse colony.

The authors declare no competing financial interests.

Correspondence should be addressed to Kevin Wickman at wickm002@umn.edu.

https://doi.org/10.1523/JNEUROSCI.2606-20.2020

Copyright $\odot 2021$ the authors

\section{Introduction}

The MPFC plays a crucial role in cognition and motivated behavior (Xu et al., 2019; Woon et al., 2020). The mPFC provides glutamatergic input to several brain regions, including the VTA, BLA, and NAc (Sesack et al., 1989; Sesack and Pickel, 1992), and these projections have been linked to key facets of cocaine addiction (Steketee and Kalivas, 2011; Xu et al., 2019; Woon et al., 2020). For example, cocaine exposure increases glutamate release in the NAc and VTA (Kalivas, 2009), and these increases and associated cocaine-induced neuroadaptations and drugseeking behavior can be blocked by MPFC inactivation (Li et al., 1999; McFarland and Kalivas, 2001; McFarland et al., 2003; Steketee, 2003; Jo et al., 2013). In addition, cocaine-induced adaptations in $\mathrm{mPFC}$ projections are critical for the development 
and expression of locomotor sensitization, a phenomenon sharing anatomic and neurochemical features with craving (Steketee and Kalivas, 2011).

The mPFC consists of cingulate, prelimbic (PL), infralimbic (IL), and orbitofrontal cortices (Xu et al., 2019; Woon et al., 2020). Numerous studies have highlighted the role of the PL in regulating addiction-related behaviors and cognition (Peters et al., 2009; Gass and Chandler, 2013; Jasinska et al., 2015; Moorman et al., 2015; Gourley and Taylor, 2016; Woon et al., 2020). For example, PL lesions prevent the induction and expression of cocaine-induced locomotor sensitization, and PL inactivation decreases the reinstatement of cocaine-seeking behavior (Pierce et al., 1998; Tzschentke and Schmidt, 1998, 2000). PL activity is also necessary for associative learning (Gilmartin et al., 2014; Giustino and Maren, 2015), which is dysregulated following repeated cocaine exposure (Goldstein and Volkow, 2011). In rodent trace fear conditioning studies, for example, persistent firing in the PL during the trace interval, the period separating the auditory cue and footshock delivery, is critical for fear learning (Fuster, 1973; Funahashi et al., 1989; Baeg et al., 2001; Compte et al., 2003; Han et al., 2003; Runyan et al., 2004; Gilmartin and McEchron, 2005; Blum et al., 2006; Gilmartin and Helmstetter, 2010; Gilmartin et al., 2013). Indeed, trace fear learning is prevented by optogenetic silencing of the PL during the trace interval (Gilmartin et al., 2013).

The PL contains excitatory pyramidal neurons $(\sim 85 \%)$ and GABAergic interneurons ( $\sim 15 \%)$ (Kawaguchi, 1993). Pyramidal neurons, particularly those in layers 5 and 6 , are primary projection neurons (Sesack et al., 1989; Sesack and Pickel, 1992), while GABA neurons regulate pyramidal neuron excitability (Kvitsiani et al., 2013; Ferguson and Gao, 2018; Slaker et al., 2018). Prolonged contingent or noncontingent cocaine exposure triggers adaptations that increase PL pyramidal neuron excitability (Dong et al., 2005; Nasif et al., 2005, 2011; Huang et al., 2007; Lu et al., 2010; Hearing et al., 2013; Otis et al., 2018; SepulvedaOrengo et al., 2018). Repeated cocaine exposure also reduces GABAergic neurotransmission in PL pyramidal neurons via suppression of presynaptic GABA release (Slaker et al., 2015), and blunting of postsynaptic $\mathrm{GABA}_{\mathrm{A}} \mathrm{R}$ - and $\mathrm{GABA}_{\mathrm{B}} \mathrm{R}$-mediated signaling (Huang et al., 2007; Hearing et al., 2013; Slaker et al., 2015). At present, the behavioral relevance of elevated PL pyramidal neuron excitability is not well understood.

Previously, we reported that a cocaine sensitization regimen increased layer 5/6 PL pyramidal neuron excitability in mice, and that this adaptation correlated with reduced $G$ protein-gated inwardly rectifying $\mathrm{K}^{+}$(GIRK/Kir3) channel activity (Hearing et al., 2013). Viral suppression of GIRK channel activity in the PL of drug-naive mice increased the motor-stimulatory effect of cocaine. This manipulation was not selective for pyramidal neurons, however, and GABA neurons regulate pyramidal neuron excitability. Since psychostimulant exposure also suppressed GIRK-dependent signaling in VTA GABA neurons (Padgett et al., 2012), we first asked whether layer 5/6 PL GABA neurons express GIRK channels, and if so, whether repeated cocaine exposure alters GIRK-dependent signaling in, or excitability of, these neurons. We then used neuron-specific viral approaches to probe the behavioral impact of manipulations that persistently or acutely enhance PL pyramidal neuron excitability.

\section{Materials and Methods}

Animals. All experiments were approved by the University of Minnesota Institutional Animal Care and Use Committee. The generation of Girk1 $1^{-/-}$(RRID:MGI:3041949), Girk2-/- (RRID:MGI:3852123), Girk3 ${ }^{-/-}$ (RRID:MGI:2676599), and Girk1 $1^{f l f l}$ mice was described previously (Signorini et al., 1997; Bettahi et al., 2002; Torrecilla et al., 2002; Marron Fernandez de Velasco et al., 2017). GAD67GFP mice were provided by Takeshi Kaneko (Tamamaki et al., 2003). CaMKIICre (B6.Cg-Tg(Camk2a-cre)T29-1Stl/J, RRID:IMSR_JAX:005359) and GADCre (B6N.Cg-Gad2 ${ }^{t m 2(c r e) Z j h} / J$, RRID:IMSR_JAX:010802) lines were purchased from The Jackson Laboratory and were maintained by backcrossing against the $\mathrm{C} 57 \mathrm{BL} / 6 \mathrm{~J}$ strain. $\mathrm{Cre}(+)$ and/or $\mathrm{Cre}(-)$ offspring were used in some experiments. Male C57BL/6J mice were purchased for some studies. Mice were maintained on a 14:10 h light/ dark cycle and were provided ad libitum access to food and water.

Chemicals. Baclofen, barium chloride, picrotoxin, and kynurenic acid were purchased from Sigma Millipore. CGP54626, clozapine-Noxide (CNO), and TTX were purchased from Tocris Bioscience. Cocaine was obtained through Boynton Health Pharmacy at the University of Minnesota.

Viral vectors. pAAV-hSyn-DIO-hM3Dq(mCherry) (RRID:Addgene 44361), pAAV-hSyn-DIO-hM4Di(mCherry) (RRID:Addgene_44362), and pAAV-hSyn-DIO-mCherry (RRID:Addgene_50459) were gifts from Bryan Roth. pAAV-CaMKII $\alpha$-hM3Dq(mCherry) and pAAVCaMKII $\alpha$-mCherry plasmids were generated by the University of Minnesota Viral Vector and Cloning Core using standard cloning techniques and pAAV-CaMKII $\alpha$-hChR2(C128S/D156A)-mCherry (RRID: Addgene_35502, a gift from Karl Deisseroth) as the backbone. Similarly, pAAV-mDlx-hM4Di(mCherry), pAAV-mDlx-mCherry, and pAAVmDlx-tdTomato were generated using pAAV-mDlx-GCaMP6f-Fishell-2 (RRID:Addgene_83899, a gift from Gordon Fishell) as the source of the mDlx promoter/enhancer. pAAV-hSyn-Cre-GFP (RRID:Addgene_68544, a gift from Eric Nestler) was packaged into AAV2retro. AAV8-CaMKII $\alpha$ Cre(mCherry) was purchased from the University of North Carolina Vector Core. All other viral vectors were packaged in AAV8 serotype by the University of Minnesota Viral Vector and Cloning Core; all viral titers were between $3.5 \times 10^{12}$ and $2.2 \times 10^{14}$ genocopies $/ \mathrm{ml}$.

Intracranial viral manipulations. Intracranial infusion of virus (400 $\mathrm{nl}$ per side) in mice (7-8 weeks) was performed as described previously (Tipps et al., 2018), using the following coordinates (in $\mathrm{mm}$ from bregma: AP, ML, DV): PL $(2.50, \pm 0.45,-1.60)$, BLA $(-1.50, \pm 3.35$, $-4.70)$, NAc $(1.50, \pm 1.00,-4.50)$, and VTA $(-2.60, \pm 0.65,-4.70)$. After surgery, animals were allowed 3-4 weeks (chemogenetic studies) or 4-5 weeks (Cre ablation or projection-specific chemogenetic studies) for full recovery and viral expression before electrophysiological or behavioral assessments. The scope and accuracy of targeting were assessed using fluorescence microscopy. Brightfield and fluorescent images were overlaid and evaluated using the mouse brain atlas (Lein et al., 2007). Targeting coordinates and viral loads yielded extensive coverage of the $\mathrm{PL}$ along the rostrocaudal axis, with limited spread into the anterior cingulate (cg), medial orbital, or IL cortices. Only data from mice in which $>70 \%$ of viral-driven bilateral fluorescence was confined to the PL were included in the final analysis. To evaluate the targeting fidelity of AAV8/CaMKII $\alpha$ - and AAV8/mDlx-based vectors, AAV8-CaMKII $\alpha$ mCherry or AAV8-mDlx-mCherry vectors were infused into the PL of GAD67GFP(+) mice. After a 2 week period, brains were fixed with $4 \%$ PFA, coronal sections $(50 \mu \mathrm{m})$ were obtained by sliding microtome, and images of viral-driven mCherry and GFP fluorescence were acquired. Quantification of cells expressing mCherry, GFP, or both (overlap) was performed with ImageJ software (Schneider et al., 2012).

Cocaine sensitization. GAD67GFP $(+)$ mice (5-8 weeks) underwent a cocaine sensitization paradigm, as described previously (Hearing et al., 2013). Briefly, mice were exposed to once-daily injections of cocaine $(15 \mathrm{mg} / \mathrm{kg}$, i.p.) or saline over 5 consecutive days before electrophysiological assessments 1-2 d later.

Slice electrophysiology. Baclofen-induced somatodendritic currents were recorded in layer 5/6 PL neurons, as described previously (Marron Fernandez de Velasco et al., 2015). For rheobase assessments, cells were held at $0 \mathrm{pA}$ in current-clamp mode and given $1 \mathrm{~s}$ current pulses, beginning at $-60 \mathrm{pA}$ and increasing in $20 \mathrm{pA}$ increments. Rheobase was identified as the injection step at which initial spiking was elicited. For PL GABA neuron recordings, rheobase was measured before and after 
perfusion of baclofen $(200 \mu \mathrm{M})$. For chemogenetic experiments, resting membrane potential (RMP) and rheobase were assessed before and after bath perfusion of CNO $(10 \mu \mathrm{M})$. sIPSCs were recorded and analyzed, as described previously (Tipps et al., 2018).

Behavioral testing. Adult mice (10-13 weeks) were evaluated in open-field motor activity and trace fear conditioning tests. For motor activity studies, mice were acclimated to handling, injection, and openfield chambers for 2-4 d before testing. For GIRK ablation experiments, distance traveled during the $60 \mathrm{~min}$ interval after saline injection on the final acclimation day was taken as baseline activity. Distance traveled after injection of cocaine $(15 \mathrm{mg} / \mathrm{kg}$, i.p.) the next day was taken as cocaine-induced activity. For chemogenetic studies, CNO $(2 \mathrm{mg} / \mathrm{kg}$, i.p.) was administered $30 \mathrm{~min}$ before saline injection and placement in the open field; distance traveled over the next $60 \mathrm{~min}$ was taken as baseline activity. Subsequently (2-4 d later), subjects were injected with CNO ( $2 \mathrm{mg} / \mathrm{kg}$, i.p.) $30 \mathrm{~min}$ before cocaine ( $15 \mathrm{mg} / \mathrm{kg}$, i.p.); distance traveled over the next $60 \mathrm{~min}$ interval was taken as cocaine-induced activity. In studies involving AAV8/mDlx-based vectors, separate cohorts of mice underwent baseline or cocaine-induced activity testing.

For trace fear conditioning studies, mice were acclimated to handling and testing room for $1-2 \mathrm{~d}$ before testing. The $6.5 \mathrm{~min}$ conditioning session (day 1) involved 2 pairings of a $30 \mathrm{~s}$ auditory cue $(65 \mathrm{~dB}$ white noise) and a $2 \mathrm{~s}$ footshock $(0.5 \mathrm{~mA})$, separated by a $30 \mathrm{~s}$ trace interval. For chemogenetic studies, $\mathrm{CNO}(2 \mathrm{mg} / \mathrm{kg}$, i.p.) was only administered once, $30 \mathrm{~min}$ before conditioning on day 1 . Cue recall was assessed on day 3 , with chambers reconfigured using a white plastic insert to cover the bar floor and a black tent insert to alter the size, shape, and color of the environment. Inserts were also cleaned with $0.1 \%$ acetic acid instead of ethanol to provide a distinct olfactory cue. Freezing was monitored throughout the $15 \mathrm{~min}$ test period, divided into $5 \times 3 \mathrm{~min}$ bins that included $2 \times 3 \mathrm{~min}$ auditory cue presentations. For projection-specific manipulations, motor activity testing was performed 3-12 d after the trace fear conditioning study.

Experimental design and statistical analysis. Data are presented as the mean \pm SEM. Statistical analyses were performed using GraphPad Prism 8 (GraphPad Software). Unless specifically noted, all studies involved balanced groups of males and females. While sex was included as a variable in preliminary analyses (Student's $t$ test, two-way ANOVA, threeway repeated-measures ANOVA, mixed-effects model REML), no impact of sex was observed on any measure and data from males and females were pooled. Pooled data were analyzed by paired and unpaired Student's $t$ test, Mann-Whitney test, one-way ANOVA, two-way ANOVA, two-way repeated-measures ANOVA, and mixed-effects model REML, as appropriate. Pairwise comparisons were performed using Bonferroni's post hoc test, if justified. Within-subjects factors include test session (saline vs cocaine, prevs post-CNO treatment) and between-subjects factors include genotype (GAD67GFP:Girk ${ }^{-/}$, GAD67GFP), drug treatment $\left(\mathrm{Ba}^{2+}, \mathrm{CNO}\right.$, cocaine, control), and viral treatment (Cre, DREADD, control vector), where appropriate. In Figure 3J, CaMKIICre(+) mice were compared with CaMKIICre $(-)$ littermate controls. Sample size $(n$ or $N)$ per group and statistical details of experiments are reported in the figure legends and Results. Data points that fell outside of the group mean by $>2.5$ SDs were excluded from analysis; this resulted in the exclusion of only one data point across the entire study. Differences were considered significant when $p<0.05$.

\section{Results}

\section{Impact of repeated cocaine on PL GABA neurons}

We used GAD67GFP $(+)$ mice to probe for the presence of GIRK channels in layer 5/6 PL GABA neurons, and to assess whether repeated cocaine evoked plasticity in GIRK-dependent signaling in these neurons (Fig. 1A). The $\mathrm{GABA}_{\mathrm{B}} \mathrm{R}$ agonist baclofen evoked an outward current in layer 5/6 PL GABA (GFP-positive) neurons that correlated with decreased input resistance; no sex difference was detected $\left(t_{(17)}=0.73, p=0.47\right.$; unpaired Student's $t$ test). Baclofen-induced responses were suppressed by $0.3 \mathrm{~mm}$ external $\mathrm{Ba}^{2+}$, consistent with GIRK channel activation (Fig. $1 B$, $C ; t_{(17)}=7.317,{ }^{* * *} p<0.0001$; unpaired Student's $t$ test).
Indeed, layer 5/6 PL GABA neurons lacking GIRK1 or GIRK2 (but not GIRK3) exhibited diminished baclofen-induced currents (Fig. 1D,E; one-way ANOVA, significant effect of genotype $\left[F_{(3,32)}=27.01, p<0.0001\right] ;$ Bonferroni's post hoc test: ${ }_{* * * *} p<0.0001\left[\right.$ Girk $1^{-/-}$vs control], ${ }^{* * *} p<0.0001\left[\mathrm{Girk2}^{-/-}\right.$vs control], and $p=0.097$ [Girk3 ${ }^{-/-}$vs control]). GIRK1 or GIRK2 ablation did not impact rheobase (Fig. $1 F$; one-way ANOVA, no effect of genotype, $\left.F_{(2,25)}=0.97, p=0.39\right)$ but did blunt the baclofen-induced increase in rheobase (Fig. $1 G$; one-way ANOVA, significant effect of genotype, $F_{(2,40)}=27.79, p<0.0001$; Bonferroni's post hoc test: ${ }^{* * *} p<0.0001$ [Girk1 ${ }^{-/-}$vs control], ${ }^{* * * *} p<0.0001$ [Girk2 $2^{-/-}$vs control]). Thus, layer 5/6 PL GABA neurons express a GIRK channel, formed by GIRK1 and GIRK2, that mediates approximately half of the $G_{A B A} R$ dependent somatodendritic current and suppression of excitability.

We next subjected GAD67GFP $(+)$ mice to a cocaine sensitization regimen involving once-daily injections of cocaine $(15 \mathrm{mg} / \mathrm{kg}$, i.p.) or saline over 5 consecutive days; this sensitization regimen was sufficient to provoke a suppression of $\mathrm{GABA}_{\mathrm{B}} \mathrm{R}-\mathrm{GIRK}$ signaling in layer 5/6 PL pyramidal neurons (Hearing et al., 2013). Cocaine-treated GAD67GFP $(+)$ mice displayed locomotor sensitization, as evidenced by a significant increase in distance traveled following the fifth cocaine injection compared with the first $\left(t_{(6)}=\right.$ $5.138,{ }^{*} p=0.0021$; paired Student's $t$ test). Subsequently (1-2 d later), we measured RMP, rheobase, and baclofen-induced currents in layer 5/6 PL GABA neurons. Repeated cocaine had no impact on baclofen-induced current amplitude (Fig. $1 H, I ; t_{(32)}=$ 0.960, $p=0.34$; unpaired Student's $t$ test), RMP (Fig. $1 J$; $t_{(31)}=$ $0.542, p=0.59$; unpaired Student's $t$ test), or rheobase (Fig. $1 K$; $t_{(30)}=0.9063, p=0.37$; unpaired Student's $t$ test).

\section{GIRK channel ablation in PL pyramidal neurons}

The lack of impact of repeated cocaine on layer 5/6 PL GABA neurons suggests that cocaine exerts a relatively selective impact on adjacent PL pyramidal neurons (Hearing et al., 2013). To probe the behavioral relevance of the GIRK neuroadaptation in layer 5/6 PL pyramidal neurons, we used a neuron-selective viral Cre approach and conditional Girk $1^{-/-}\left(\right.$Girk $\left.1^{f l f l}\right)$ mice (Fig. 2A). The CaMKII $\alpha$ promoter has been used extensively to drive transgene expression in PFC pyramidal neurons (Volle et al., 2016; Warthen et al., 2016; Pati et al., 2018; Zhang et al., 2020). To evaluate the fidelity of pyramidal neuron targeting with our AAV8/CaMKII $\alpha$-based vectors, we infused AAV8-CaMKII $\alpha$ mCherry into the PL of GAD67GFP $(+)$ mice. Only a small fraction (4\%) of neurons coexpressed GFP and mCherry (Fig. 2B), suggesting that AAV8/CaMKII $\alpha$-based vectors primarily target pyramidal neurons in the PL.

AAV8-CaMKII $\alpha$-Cre(mCherry) or AAV8-CaMKII $\alpha$-mCherry vectors were infused into the PL of Girk $1^{f / f l}$ mice. Following a 4-5 week recovery period, we evaluated the impact of viral Cre and control treatment on mCherry-positive layer 5/6 PL neurons. Viral Cre treatment yielded smaller baclofen-induced currents in these neurons (Fig. $2 C, D ; t_{(20)}=4.33,{ }^{* * *} p=0.0003$; unpaired Student's $t$ test). While loss of GIRK channel activity had no impact on RMP (Fig. $2 E ; t_{(21)}=0.64, p=0.53$; unpaired Student's $t$ test), rheobase was decreased (Fig. 2F; $t_{(21)}=4.32,{ }^{* * *} p=0.0003$; unpaired Student's $t$ test), consistent with an increase in excitability.

To assess the behavioral consequences of the manipulation, Girk $1^{f l f l}$ mice were infused with $\mathrm{CaMKII} \alpha$-Cre(mCherry) or control vector, followed by open-field activity assessments. Suppression of GIRK channel activity in PL pyramidal neurons did not impact distance traveled following saline injection 

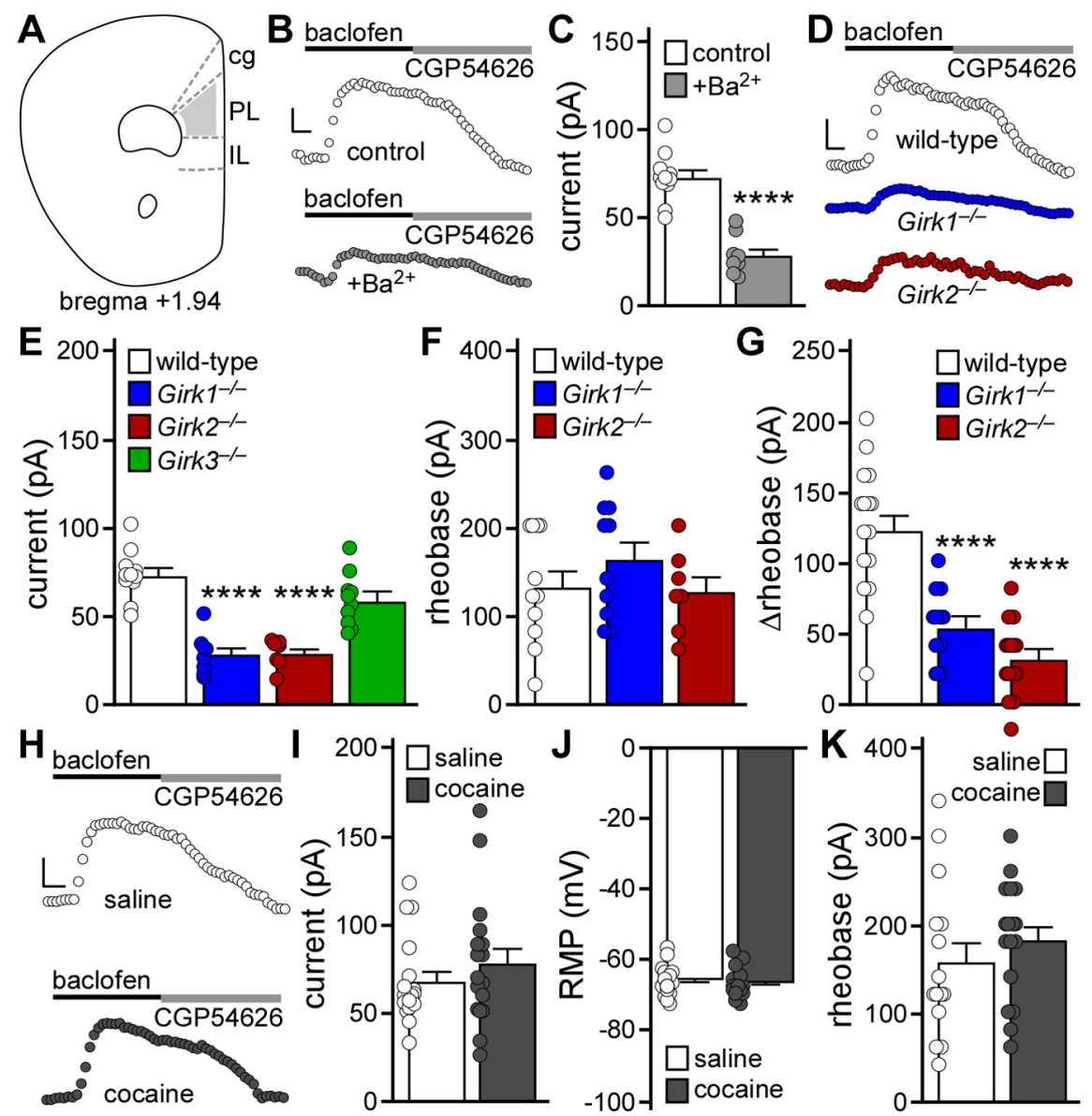

Figure 1. Impact of repeated cocaine exposure on layer 5/6 PL GABA neurons. A, Schematic highlighting the PL, and adjacent cingulate $(\mathrm{cg})$ and IL cortices. GFP-positive (GABA) neurons in layer 5/6 of the PL, in slices from GAD67GFP(+) mice, were targeted for analysis. $B$, Somatodendritic currents $\left(V_{\text {hold }}=-60 \mathrm{mV}\right)$ evoked by baclofen $(200 \mu \mathrm{m})$ in GABA neurons from $G A D 67 G F P(+)$ mice, in the absence and presence of external $0.3 \mathrm{~mm} \mathrm{Ba}{ }^{2+}$. Currents were reversed by the $G_{A B A} R$ antagonist CGP54626 $(2 \mu \mathrm{m})$. Calibration: $25 \mathrm{pA} / 50 \mathrm{~s}$. C, Baclofen-induced currents in GABA neurons from GAD67GFP(+) mice, in the absence (control) and presence of $0.3 \mathrm{~mm} \mathrm{Ba}^{2+}$ (****p $<0.0001$; unpaired Student's $t$ test; $n=8$-11 recordings/ group and $N=2-4$ male mice/group). $D$, Currents evoked by baclofen $(200 \mu \mathrm{m})$ in GABA neurons from male GAD67GFP(+) (WT), GAD67GFP(+):Girk ${ }^{-/-}\left(\right.$Girk $\left.1^{-1-}\right)$, and GAD67GFP(+):Girk2 ${ }^{-1-}\left(\right.$ Girk2 $\left.{ }^{-1}\right)$ mice. Calibration: $25 \mathrm{pA} / 50 \mathrm{~s}$. E, Baclofeninduced currents in GABA neurons from GAD67GFP(+) and GAD67GFP(+):Girk ${ }^{-1-}$ mice (****p $<0.0001$; one-way ANOVA with Bonferroni's post hoc test; $n=7-11$ recordings/group and $N=2-4$ male mice/group). Data used in the control group (WT) were the same as used in $\boldsymbol{C}$ (control group). $\boldsymbol{F}$, Baseline rheobase in GABA neurons from GAD67GFP(+) and GAD67GFP $(+):$ Girk $^{-1-}$ mice (one-way ANOVA; $n=7-11$ recordings/group and 2-4 male mice/group). $\mathbf{G}$, Change in rheobase induced by baclofen $(200 \mu \mathrm{m})$ in GABA neurons from GAD67GFP(+) and GAD67GFP(+):Girk ${ }^{-1-}$ mice $(* * * * p<0.0001$; one-way ANOVA with Bonferroni's post hoc test; $n=12-16$ recordings/group and $N=5$ or 6 mice/group). No main effect of sex was detected $\left(F_{(1,37)}=0.654, p=0.42\right.$; two-way ANOVA). $\boldsymbol{H}$, Currents evoked by baclofen $(200 \mu \mathrm{M})$ in GABA neurons from $\operatorname{GAD67GFP}(+)$ mice, 1-2 $d$ after repeated saline or cocaine treatment. Currents were reversed by the $G_{A B A} R$ antagonist CGP54626 $(2 \mu \mathrm{m})$. Calibration: $25 \mathrm{pA} / 50 \mathrm{~s}$. I, Baclofen-induced currents in GABA neurons from GAD67GFP(+) mice, 1-2 d after repeated saline or cocaine treatment (unpaired Student's $t$ test; $n=17$ recordings/group and $N=7$ mice/group). No main effect of sex was detected $\left(F_{(1,30)}=0.0004, p=0.98\right.$; two-way ANOVA). J, RMP in GABA neurons from GAD67GFP(+) mice, 1-2 d after repeated saline or cocaine treatment (unpaired Student's $t$ test; $n=16$ or 17 recordings/group and $N=7$ mice/group). No main effect of sex was detected $\left(F_{(1,29)}=3.400, p=0.075\right.$; two-way ANOVA). $\boldsymbol{K}$, Rheobase in GABA neurons from GAD67GFP( + ) mice, 1-2 d after repeated saline or cocaine treatment (unpaired Student's $t$ test; $n=15-17$ recordings/ group and $N=7$ mice/group). No main effect of sex was detected $\left(F_{(1,28)}=0.075, p=0.79\right.$; two-way ANOVA).

(baseline) but did enhance the motor-stimulatory effect of acute cocaine $(15 \mathrm{mg} / \mathrm{kg}$, i.p.) (Fig. $2 G$; two-way repeated-measures ANOVA, significant interaction between drug and viral treatment, $F_{(1,15)}=7.71, p=0.014$; Bonferroni's post hoc test, ${ }^{\star} p=0.011$ [Cre vs control vector, with respect to cocaine-induced locomotion]), recapitulating the behavioral impact of RNAibased suppression of GIRK channel activity in PL neurons (Hearing et al., 2013). In a separate cohort, we tested the impact of the manipulation on trace fear conditioning, an associative learning task dependent on PL function (Gilmartin et al., 2013, 2014; Giustino and Maren, 2015). Loss of GIRK channel activity in PL pyramidal neurons was associated with decreased cue fear recall, although the difference between Cre-treated and control subjects did not reach statistical significance (Fig. 2H; $U=62.0, p=0.063$; unpaired nonparametric Mann-Whitney test). Thus, loss of GIRK channel activity in PL pyramidal neurons enhanced the motor-stimulatory effect of cocaine but did not significantly impact baseline activity or trace fear learning.

\section{Chemogenetic excitation of PL pyramidal neurons}

As repeated cocaine is associated with multiple adaptations that enhance mPFC pyramidal neuron excitability, we sought to complement the persistent viral Cre manipulation of GIRK channel activity with chemogenetic approaches to acutely enhance PL pyramidal neuron excitability. AAV8-CaMKII $\alpha$-hM3Dq(mCherry) or AAV8-CaMKII $\alpha$-mCherry vectors were infused into the PL of C57BL/6J mice (Fig. $3 A$ ). Following a 3-4 week recovery, we tested whether chemogenetic excitation enhanced layer 5/6 PL pyramidal neuron excitability. Bath application of CNO $(10 \mu \mathrm{M})$ significantly depolarized (Fig. $3 B ; \Delta \mathrm{RMP}, t_{(8.86)}=4.39,{ }^{* *} p=0.0018$; unpaired Student's $t$ test with Welch's correction) and decreased the rheobase (Fig. $3 C$; $\Delta$ rheobase, $t_{(12)}=5.82,{ }^{* * *} p<0.0001$; unpaired Student's $t$ test) of hM3Dq (mCherry)-expressing, but not control, layer 5/6 PL pyramidal neurons.

We next examined the impact of chemogenetic excitation of PL pyramidal neurons on motor activity and trace fear conditioning. CNO pretreatment elevated activity measured after both saline and cocaine injection in $\mathrm{hM} 3 \mathrm{Dq}$ (mCherry)expressing $\mathrm{C} 57 \mathrm{BL} / 6 \mathrm{~J}$ mice, relative to controls (Fig. 3D; two-way repeatedmeasures ANOVA, main effects of drug $\left[F_{(1,16)}=63.29, p<0.0001\right]$ and viral $\left[F_{(1,16)}=15.01,{ }^{\# \#} p=0.0013\right]$ treatment, no interaction between drug and viral treatment $\left.\left[F_{(1,16)}=0.70, p=0.414\right]\right)$. Chemogenetic excitation of PL pyramidal neurons during trace fear conditioning was associated with lower freezing levels during the subsequent cue recall test (Fig. $3 E ; t_{(23)}=2.23,{ }^{\star} p=0.036$; unpaired Student's $t$ test). In a parallel study, we used the well-characterized CaMKIICre line and Cre-dependent AAV vectors to drive expression of $\mathrm{hM} 3 \mathrm{Dq}(\mathrm{mCherry})$ or mCherry in PL pyramidal neurons (Fig. $3 F)$. In slice validation experiments, CNO $(10 \mu \mathrm{M})$ depolarized (Fig. $3 G$; $\Delta \mathrm{RMP}, t_{(7)}=6.34$, ${ }^{* * *} p=0.0004$; unpaired Student's $t$ test with Welch's correction) and decreased the 
rheobase (Fig. $3 H ; \Delta$ rheobase, $t_{(14.26)}=5.58$, ${ }^{* * * *} p<0.0001$; unpaired Student's $t$ test with Welch's correction) of hM3Dq(mCherry)expressing layer 5/6 PL neurons. CNO pretreatment elevated motor activity measured after both saline and cocaine injection in $\mathrm{hM} 3 \mathrm{Dq}$ (mCherry)-expressing mice (Fig. 3I; mixedeffects model, main effects of drug $\left[F_{(1,12)}=\right.$ 59.57, $p<0.0001]$ and viral $\left[F_{(1,15)}=18.32\right.$, $\# \#=0.0007]$ treatment, no interaction between drug and viral treatment $\left[F_{(1,12)}=0.98, p=\right.$ $0.34]$ ), and chemogenetic excitation of PL pyramidal neurons during trace fear conditioning decreased cue fear recall (Fig. 3J; $t_{(20)}=3.23$, ${ }^{* *} p=0.0042$; unpaired Student's $t$ test). Thus, acute excitation of PL pyramidal neurons increased motor activity at baseline and following cocaine injection, and disrupted trace fear learning.

\section{Chemogenetic inhibition of PL GABA neurons}

Prolonged cocaine exposure reduces GABAergic neurotransmission in PL pyramidal neurons (Huang et al., 2007; Hearing et al., 2013; Slaker et al., 2015), which should indirectly enhance PL pyramidal neuron excitability. Indeed, chemogenetic inhibition of layer 5/6 PL GABA neurons decreased the frequency of sIPSCs in adjacent pyramidal neurons (Fig. $4 A-C$; $t_{(3)}=$ $4.32,{ }^{\star} p=0.023$; paired Student's $t$ test). To mimic reduced GABAergic input to PL pyramidal neurons in drug-naive C57BL/6J mice, we used a viral chemogenetic approach involving the forebrain GABAergic neuron promoter/ enhancer mDlx (Dimidschstein et al., 2016) to acutely inhibit PL GABA neurons (Fig. 4D). To test whether AAV8/mDlx-based vectors selectively targeted PL GABA neurons, we infused AAV8-mDlx-mCherry into the PL of GAD67GFP $(+)$ mice. A large majority (76\%) of PL neurons coexpressed GFP and mCherry, and a small fraction (7\%) expressed only mCherry (Fig. 4E). Thus, AAV8/mDlx-based vectors afford relatively selective access to mouse PL GABA neurons. Notably, CNO hyperpolarized (Fig. $4 F ; \triangle \mathrm{RMP}, t_{(18.07)}=$ $11.08,{ }^{* * * *} p<0.0001$; unpaired Student's $t$ test with Welch's correction) and increased the rheobase (Fig. 4G; $\Delta$ rheobase, $t_{(23.3)}=3.948$, ${ }^{* *} p=0.0006$; unpaired Student's $t$ test with Welch's correction) of hM4Di(mCherry)expressing layer 5/6 PL GABA neurons in C57BL/6J mice.

We next examined the impact of chemogenetic inhibition of PL GABA neurons on motor activity and trace fear conditioning in C57BL/6J mice. CNO pretreatment elevated motor activity measured after both saline and cocaine injection in hM4Di(mCherry)-treated subjects, compared with controls (Fig. $4 \mathrm{H}$; two-way ANOVA, main effects of drug $\left[F_{(1,28)}=37.99, p<0.0001\right]$ and viral $\left[F_{(1,28)}=60.70\right.$, $\# \# \#<0.0001]$ treatment, no interaction between drug and viral treatment $\left.\left[F_{(1,28)}=0.416, p=0.52\right]\right)$, and chemogenetic inhibition of PL GABA neurons during trace fear conditioning

A

C

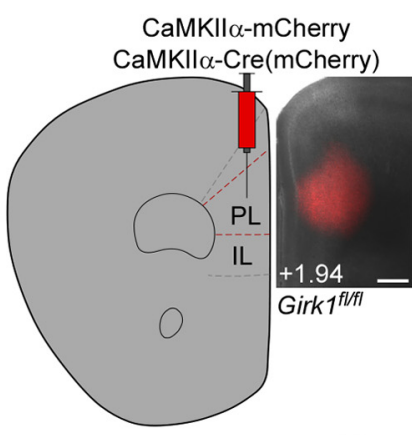

B

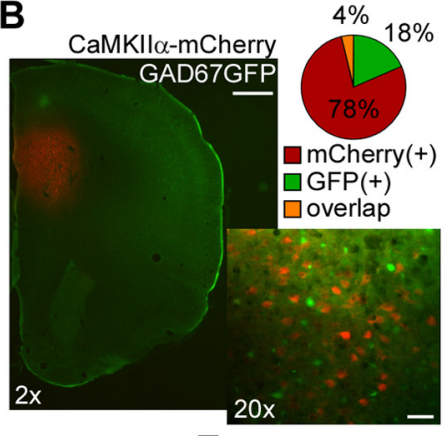

baclofen

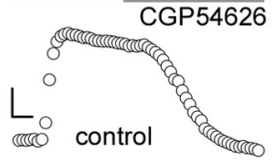

baclofen

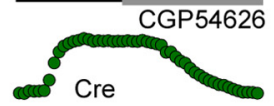

D $300-1$

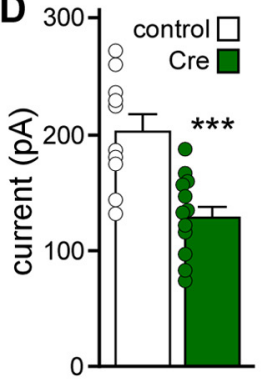

E
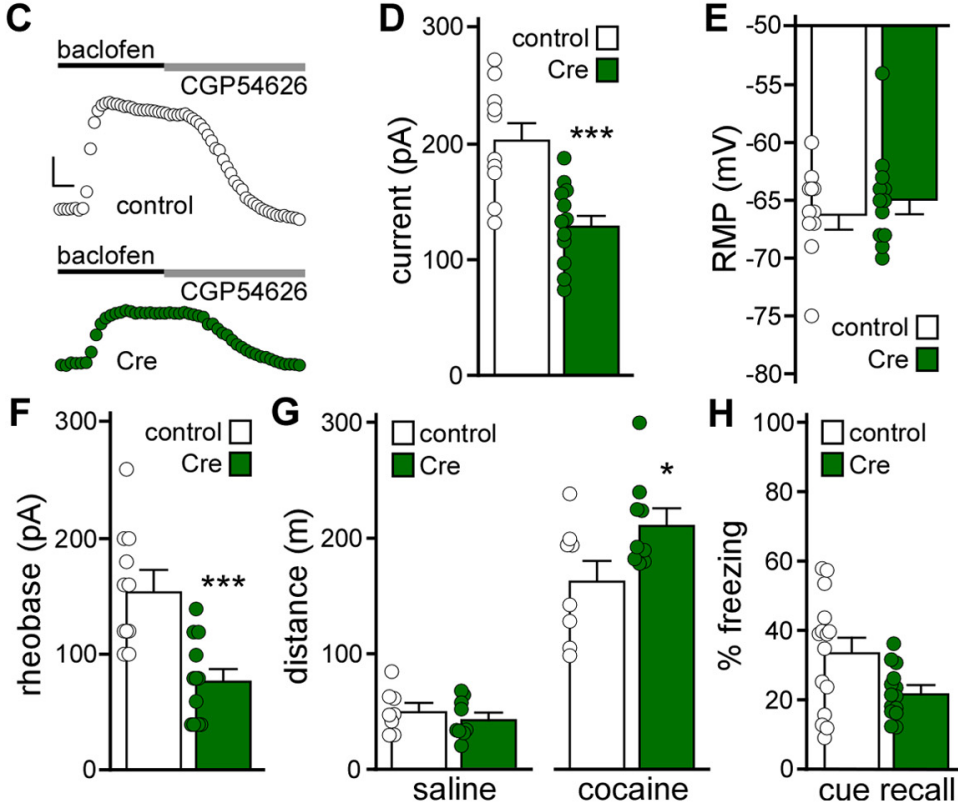

Figure 2. Viral Cre ablation of GIRK channels in PL pyramidal neurons. A, Example of viral targeting in a Girk $7^{f / / f}$ mouse treated with AAV8-CaMKII $\alpha$-Cre(mCherry) vector. Scale bar, $325 \mu \mathrm{m}$. $\boldsymbol{B}$, AAV8-CaMKII $\alpha$-mCherry labeling in the PL of a $G A D 67 G F P(+)$ mouse, and a pie chart representing percentage of fluorescent neurons expressing mCherry, GFP, or both (overlap) ( $n=935, n=222$, and $n=45$ neurons, respectively; $N=3$ mice). Scale bars: $2 \times$, $500 \mu \mathrm{m} ; 20 \times, 50 \mu \mathrm{m}$. C, Currents evoked by baclofen $(200 \mu \mathrm{m})$ in layer $5 / 6$ PL pyramidal neurons from Girk $7^{f / f f l}$ mice treated with CaMKII $\alpha$-Cre(mCherry) or control vector. Currents were reversed by the $\mathrm{GABA}_{\mathrm{B}} \mathrm{R}$ antagonist CGP54626 (2 $\mu \mathrm{m})$. Calibration: $50 \mathrm{pA} / 50$ s. D. Baclofen-induced currents in layer 5/6 PL pyramidal neurons from Girk $1^{f l / f l}$ mice treated with CaMKIl $\alpha$-Cre(mCherry) or control vector. $* * * p<0.001$ (unpaired Student's $t$ test). $n=10-12$ recordings/group and $N=3-6$ mice/group. No main effect of sex was detected $\left(F_{(1,18)}=0.15, p=0.71\right.$; two-way ANOVA). $\boldsymbol{E}, \mathrm{RMP}$ in layer 5/6 PL pyramidal neurons from Girk $1^{f / / f}$ mice treated with CaMKIl $\alpha$-Cre(mCherry) or control vector (unpaired Student's $t$ test; $n=11$ or 12 recordings/group and $N=3-6$ mice/group). No main effect of sex was detected $\left(F_{(1,19)}=0.079, p=0.78\right.$; two-way ANOVA). $\boldsymbol{F}$, Rheobase in layer 5/6 PL pyramidal neurons from Girk $7^{f l / f l}$ mice treated with CaMKIl $\alpha$-Cre(mCherry) or control vector. $* * * p<0.001$ (unpaired Student's $t$ test). $n=11$ or 12 recordings/group and $N=3-6$ mice/group. No main effect of sex was detected $\left(F_{(1,19)}=1.11\right.$, $p=0.31$; two-way ANOVA). $G$, Saline- and acute cocaine-induced $\left(15 \mathrm{mg} / \mathrm{kg}\right.$, i.p.) motor activity in Girk $7^{f / f l}$ mice treated with CaMKII $\alpha$-Cre(mCherry) or control vector. $* p<0.05$ (two-way repeated-measures ANOVA with Bonferroni's post hoc test). $N=8$ or 9 mice/group. No main effect of $\operatorname{sex}\left(F_{(1,13)}=0.061, p=0.81\right)$ or sex interactions were detected (three-way repeated-measures ANOVA). $\boldsymbol{H}$, Trace fear conditioning in Girk $7^{f / f l}$ mice treated with CaMKII $\alpha$-Cre(mCherry) or control vector. Percent freezing observed during cue recall test, conducted $2 \mathrm{~d}$ after trace fear conditioning (unpaired nonparametric Mann-Whitney test; $N=14$ or 15 mice/group). No main effect of sex was detected $\left(F_{(1,26)}=3.271, p=0.082\right.$; two-way ANOVA). One outlier animal was excluded. was associated with decreased cue fear recall (Fig. $4 I ; t_{(13)}=2.20$, ${ }^{\star} p=0.047$; unpaired Student's $t$ test). Thus, chemogenetic inhibition of PL GABA neurons, such as chemogenetic excitation of PL pyramidal neurons, increased motor activity at baseline and following cocaine injection, and disrupted trace fear learning.

\section{Chemogenetic excitation of distinct PL projections}

We next used a projection-specific viral chemogenetic approach to manipulate PL neurons projecting to the BLA, NAc, or VTA 

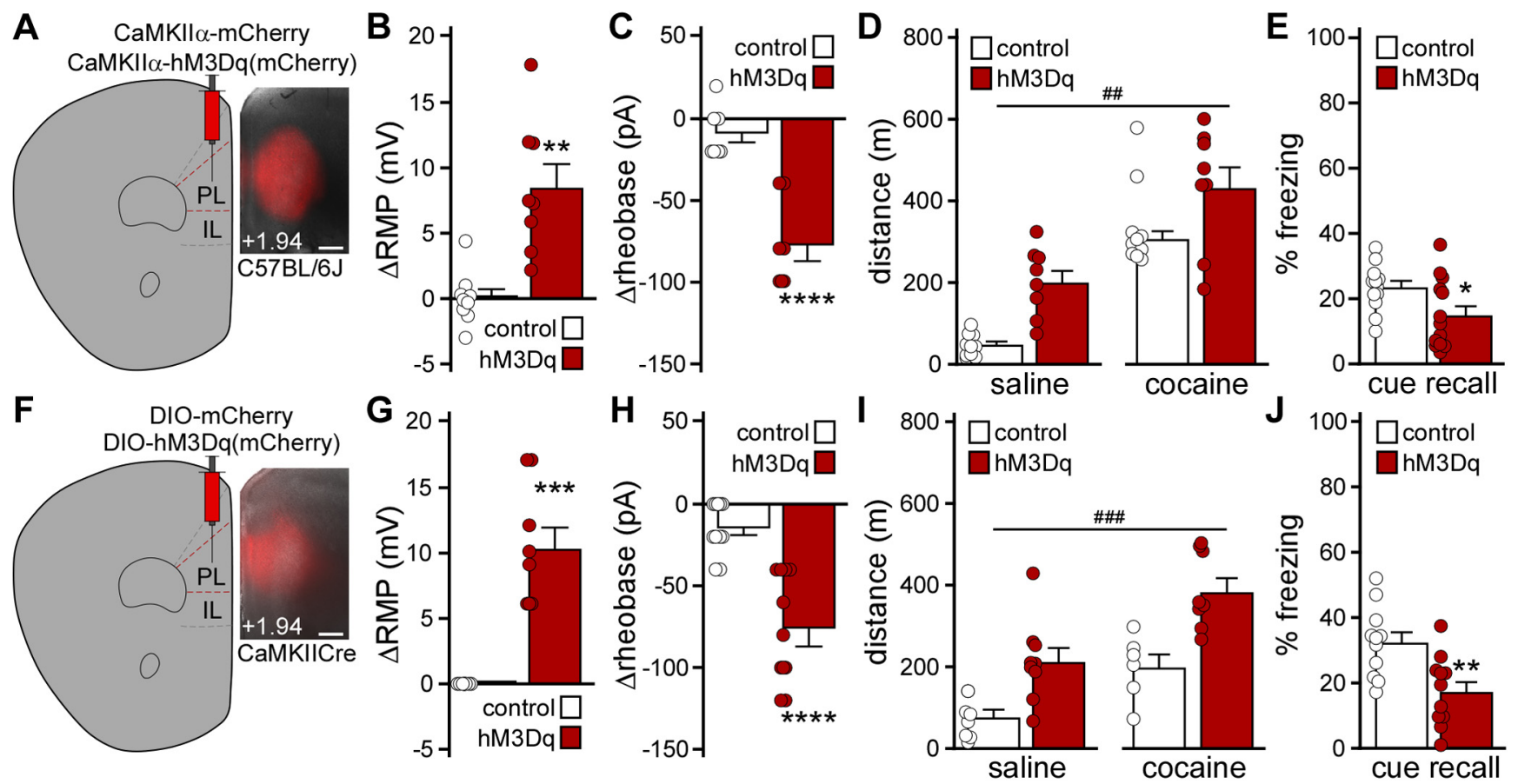

Figure 3. Impact of chemogenetic excitation of PL pyramidal neurons on behavior. A, Example of viral targeting in a (57BL/6J mouse treated with AAV8-CaMKIl $\alpha$-hM3Dq(mCherry). Scale bar, $325 \mu \mathrm{m}$. B, Change in RMP induced by CNO (10 $\mu \mathrm{m})$ in layer 5/6 PL pyramidal neurons from male C57BL/6J mice treated with AAV8-CaMKII $\alpha$-hM3Dq(mCherry) or control vector. $* * p<0.01$ (unpaired Student's $t$ test with Welch's correction). $n=8$ or 9 recordings/group and $N=3$ mice/group. C, Change in rheobase induced by CNO (10 $\mu \mathrm{m}$ ) in layer $5 / 6$ PL pyramidal neurons from male C57BL/6J mice treated with CaMKII $\alpha$-hM3Dq(mCherry) or control vector. $* * * * p<0.0001$ (unpaired Student's $t$ test). $n=7$ recordings/ group and $N=3$ mice/group. D, Saline- and acute cocaine-induced ( $15 \mathrm{mg} / \mathrm{kg}$, i.p.) motor activity in male C57BL/6J mice treated with CaMKII $\alpha$-hM3Dq(mCherry) or control vector, measured $30 \mathrm{~min}$ after CNO administration $\left(2 \mathrm{mg} / \mathrm{kg}\right.$, i.p.). ${ }^{\#} p<0.01$ (main effect of viral treatment). $N=8-10$ mice/group. $\boldsymbol{E}$, Trace fear conditioning in male C57BL/6J mice treated with CaMKII $\alpha$-hM3Dq(mCherry) or control vector. Percent freezing observed during cue recall test, conducted $2 \mathrm{~d}$ after trace fear conditioning in the presence of CNO (2 mg/kg, i.p.). $* p<0.05$ (unpaired Student's $t$ test). $N=12$ or 13 mice/group. $F$, Example of viral targeting in a CaMKI/Cre(+) mouse treated with AAV8-hSyn-DIO$\mathrm{mCherry}$. Scale bar, $325 \mu \mathrm{m}$. G, Change in RMP induced by CNO $(10 \mu \mathrm{m})$ in layer 5/6 PL pyramidal neurons from CaMKIICre $(+)$ mice treated with DI0-hM3Dq(mCherry) or control vector. $* * * p<0.001$ (unpaired Student's $t$ test with Welch's correction). $n=8-11$ recordings/group and $N=3-5$ mice/group. No main effect of sex was detected $\left(F_{(1,15)}=1.94\right.$, $p=0.18$; two-way ANOVA). $\boldsymbol{H}$, Change in rheobase induced by CNO $(10 \mu \mathrm{m})$ in layer 5/6 PL pyramidal neurons from CaMKIICre $(+)$ mice treated with DI0-hM3Dq(mCherry) or control vector. $* * * * p<0.0001$ (unpaired Student's $t$ test with Welch's correction). $n=11$ recordings/group and $N=3-5$ mice/group. No main effect of sex was detected $\left(F_{(1,18)}=\right.$ $0.82, p=0.38$; two-way ANOVA). I, Saline- and acute cocaine-induced $(15 \mathrm{mg} / \mathrm{kg})$ motor activity in CaMKIICre $(+)$ mice treated with DI0-hM3Dq(mCherry) or control vector, measured $30 \mathrm{~min}$ after systemic CNO administration $\left(2 \mathrm{mg} / \mathrm{kg}\right.$, i.p.). ${ }^{\# \#} p<0.001$ (main effect of viral treatment). $N=6-9$ mice/group. No main effect of sex $\left(F_{(1,13)}=2.224\right.$, $p=0.16)$ or sex interactions were detected (mixed-effects model). J, Trace fear conditioning in CaMKIICre(+) (hM3Dq) and CaMKIICre(-) (control) mice treated with DI0-hM3Dq (mCherry) vector. Percent freezing observed during the cue recall test, conducted $2 \mathrm{~d}$ after trace fear conditioning in the presence of CNO ( $2 \mathrm{mg} / \mathrm{kg}$, i.p.). $* * p<0.01$ (unpaired Student's $t$ test). $N=11$ mice/group. No main effect of sex was detected $\left(F_{(1,18)}=1.48, p=0.24\right.$; two-way ANOVA).

(Brinley-Reed et al., 1995; Carr and Sesack, 2000; Vertes, 2004; Otis et al., 2017). These brain regions were selected because they receive glutamatergic input from the PL and regulate fear learning and/or motor activity (Herzig and Schmidt, 2007; Steketee and Kalivas, 2011; Abraham et al., 2014; Wendler et al., 2014; Kochli et al., 2015; Runegaard et al., 2019; Kirry et al., 2020). We infused an AAV2retro-based (Tervo et al., 2016) Cre vector (AAV2retro-hSyn-Cre-GFP) into the downstream target of interest, and a Cre-dependent vector (AAV8-hSyn-DIO-hM3Dq (mCherry) or AAV8-hSyn-DIO-mCherry) into the PL (Fig. 5A, $B, E, H)$. The impact of chemogenetic excitation of each PL projection was first assessed using trace fear conditioning 4-5 weeks after surgery. While excitation of PL pyramidal neurons projecting to the BLA (Fig. $5 C ; t_{(17)}=0.543, p=0.59$; unpaired Student's $t$ test) or NAc (Fig. $5 F ; t_{(18)}=1.109, p=0.28$; unpaired Student's $t$ test) during trace fear conditioning did not affect cue fear recall, excitation of VTA-projecting PL pyramidal neurons disrupted cue fear learning (Fig. $5 I ; t_{(19)}=2.667,{ }^{*} p=0.0152$; unpaired Student's $t$ test).

We next assessed the impact of exciting each PL projection on motor activity. Chemogenetic excitation of
BLA-projecting PL pyramidal neurons did not impact salineinduced activity but did suppress cocaine-induced activity (Fig. 5D; two-way repeated-measures ANOVA, significant interaction between drug and viral treatment $\left[F_{(1,17)}=13.17\right.$, $p=0.0021]$; Bonferroni's post hoc test, ${ }^{* * * *} p<0.0001$ [DREADD vs control vector, with respect to cocaine-induced locomotion]). Chemogenetic excitation of NAc-projecting PL pyramidal neurons had no effect on saline- or cocaineinduced motor activity (Fig. 5G; two-way repeated-measures ANOVA, main effect of drug treatment $\left[F_{(1,18)}=99.73\right.$, $p<0.0001]$, no main effect of viral treatment $\left[F_{(1,18)}=2.795\right.$, $p=0.11]$, or interaction between drug and viral treatment $\left.\left[F_{(1,18)}=0.74, p=0.40\right]\right)$. Excitation of VTA-projecting PL pyramidal neurons enhanced activity measured after saline or cocaine injection (Fig. 5J; two-way repeated-measures ANOVA, main effects of drug $\left[F_{(1,19)}=40.65, p<0.0001\right]$ and viral $\left[F_{(1,19)}=21.78,{ }^{\# \# \#} p=0.0002\right]$ treatment, no interaction between drug and viral treatment $\left[F_{(1,19)}=1.986\right.$, $p=0.17])$. Thus, acute excitation of VTA-projecting PL pyramidal neurons recapitulated the motor activity and trace fear learning phenotypes seen with comprehensive excitation of PL pyramidal neurons. 


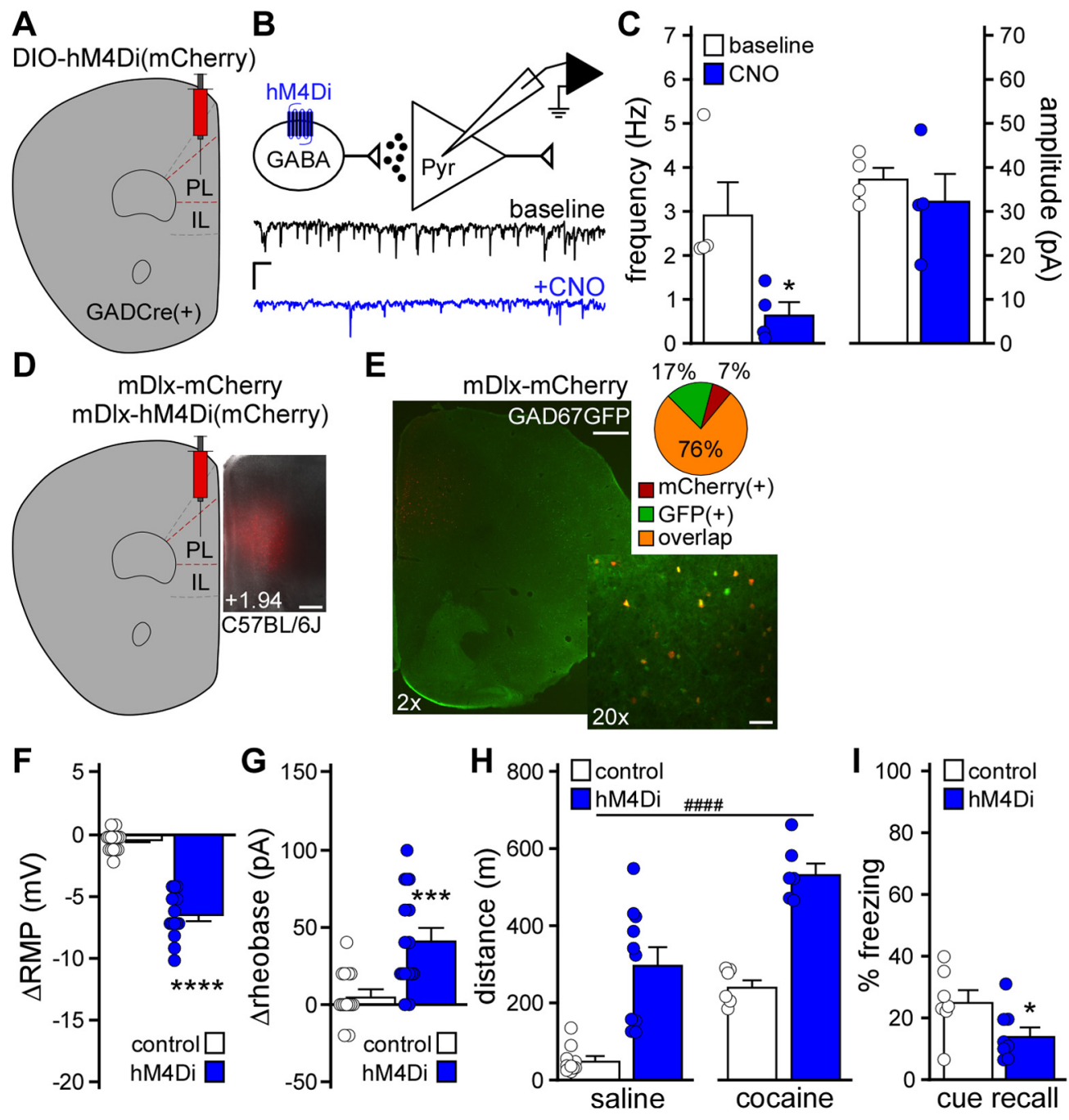

Figure 4. Impact of chemogenetic inhibition of PL GABA neurons on behavior. A, GADCre(+) mice were treated with intra-PL AAV8-hSyn-DI0-hM4Di(mCherry) vector. $\boldsymbol{B}$, sIPSCs were recorded in layer 5/6 PL pyramidal neurons from GADCre $(+)$ mice treated with DI0-hM4Di(mCherry) vector $\left(\mathrm{V}_{\text {hold }}=-70 \mathrm{mV}\right)$, before (baseline) and after bath application of CNO $(10 \mu \mathrm{m})$. Calibration: 20 pA/1 s. C, sIPSC frequency and amplitude in layer 5/6 PL pyramidal neurons, measured before and after CNO (10 $\mu \mathrm{m})$ application in slices from $G A D C r e(+)$ mice treated with DI0-hM4Di(mCherry) vector. $* p<0.05$ (paired Student's $t$ test). $n=4$ recordings/group and $N=2$ male mice/group. $D$, Example of viral targeting in a C57BL/6J mouse treated with AAV8-mDlx-mCherry. Scale bar, $325 \mu \mathrm{m}$. $E$, AAV8-mDlx-mCherry labeling in the PL of GAD67GFP( + ) mouse, and pie chart representing percent of fluorescent neurons expressing mCherry, GFP, or both (overlap) ( $n=26, n=62$, and $n=286$ neurons, respectively; $N=3$ mice). Scale bars: $2 \times, 500 \mu \mathrm{m} ; 20 \times, 50 \mu \mathrm{m}$. $\boldsymbol{F}$, Change in RMP induced by CN0 $(10 \mu \mathrm{m})$ in layer 5/6 PL GABA neurons from male C57BL/6J mice treated with mDlx-hM4Di(mCherry) or control vector. $* * * * p<0.0001$ (unpaired Student's $t$ test with Welch's correction). $n=14$ recordings/group and $N=6$ mice/group. G, Change in rheobase induced by CNO (10 $\mu \mathrm{m}$ ) in layer 5/6 PL GABA neurons from male C57BL/6J mice treated with mDlx-hM4Di(mCherry) or control vector. ***p $<0.001$ (unpaired Student's $t$ test with Welch's correction). $n=14-16$ recordings/group and $N=6$ mice/group. $\boldsymbol{H}$, Saline- and acute cocaine-induced $(15 \mathrm{mg} / \mathrm{kg}$, i.p.) motor activity in separate cohorts of male (57BL/6J mice treated with $\mathrm{mDlx}$-hM4Di(mCherry) or control vector, measured $30 \mathrm{~min}$ after CNO administration $\left(2 \mathrm{mg} / \mathrm{kg}\right.$, i.p.). ${ }^{\# \# \#} p<0.0001$ (main effect of viral treatment). $N=6-10$ mice/group. $I$, Trace fear conditioning in male C57BL/6J mice treated with $\mathrm{mDlx}-\mathrm{hM} 4 \mathrm{Di}(\mathrm{mCherry})$ or control vector. Percent freezing observed during the cue recall test, conducted $2 \mathrm{~d}$ after trace fear conditioning in the presence of CNO (2 mg/kg, i.p.). $* p<0.05$ (unpaired Student's $t$ test). $N=7$ or 8 mice/group.

\section{Discussion}

Previously, we reported that repeated cocaine exposure increased layer 5/6 PL pyramidal neuron excitability, likely because of a suppression of GIRK-dependent signaling (Hearing et al., 2013). The adaptations required $\mathrm{D}_{1}$ dopamine receptor activation, implicating mesocortical dopaminergic neurotransmission. These adaptations were evident during early withdrawal (1-2 d after the last cocaine injection) and were not seen in adjacent layer $2 / 3$ pyramidal neurons or layer 5/6 IL pyramidal neurons. Using an identical cocaine treatment regimen and timeline, we found that repeated cocaine does not impact GIRK-dependent signaling in, or excitability of, layer 5/6 PL GABA neurons. As some cocaine-induced adaptations are evident at earlier (Slaker et al., 2018) or later (Campanac and Hoffman, 2013) withdrawal time points, our cocaine treatment regimen may evoke adaptations in layer 5/6 PL GABA neurons outside the 1-2 d withdrawal window. It is also possible that repeated cocaine provokes adaptations in distinct interneuron subpopulations (Slaker et al., 2018).

RNAi-based suppression of GIRK channel expression in the PL enhanced the motor-stimulatory effect of cocaine (Hearing et al., 2013). Here, we show that selective suppression of GIRK channel activity in PL pyramidal neurons recapitulates this phenotype. This finding aligns with other reports implicating the PL and $\mathrm{GABA}_{\mathrm{B}} \mathrm{R}$-dependent signaling in locomotor sensitization. For example, PL lesions blocked the induction and expression of 
A

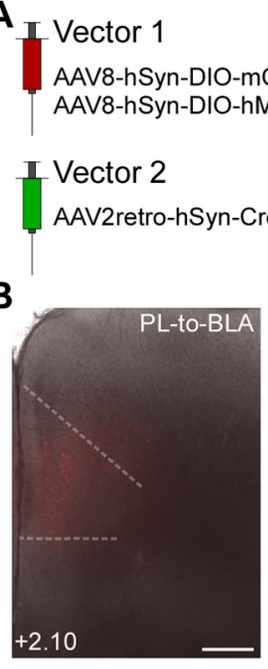

E

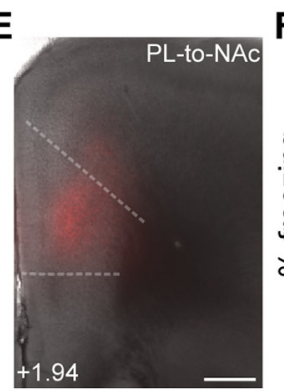

H

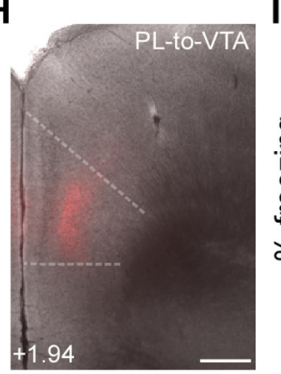

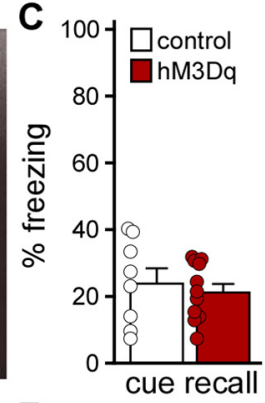

F cue recall
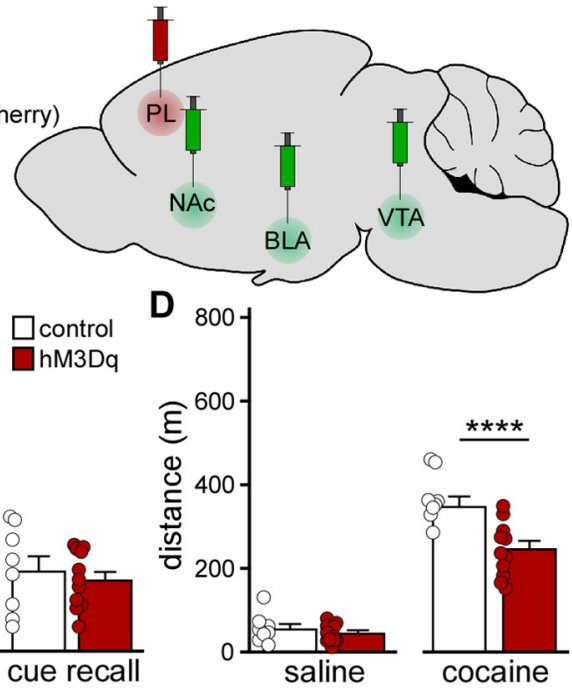

G 800
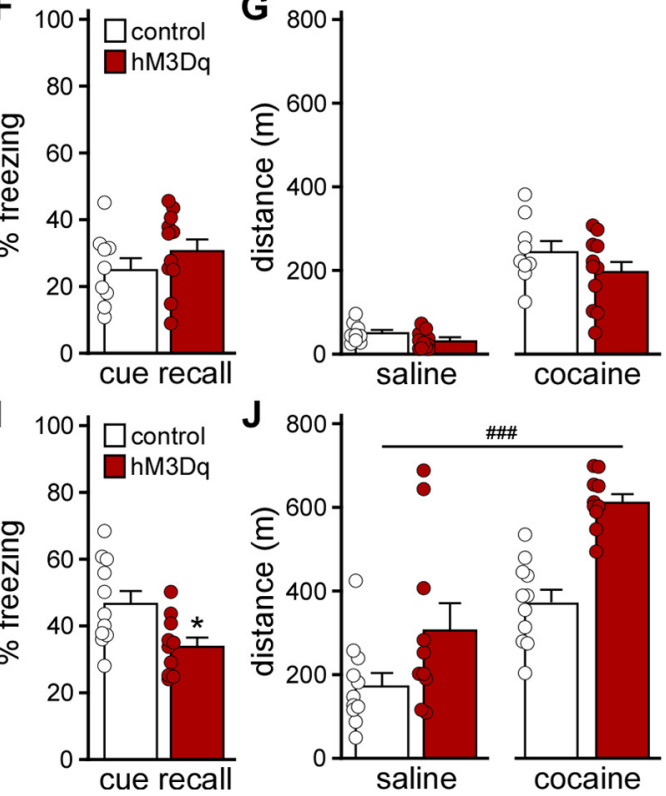

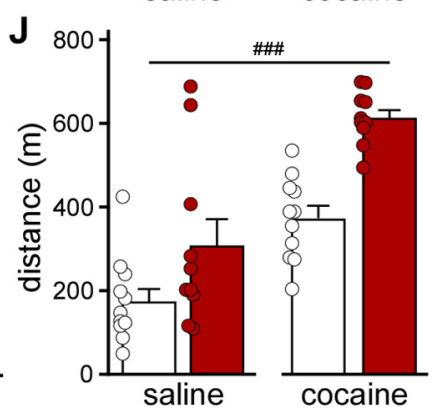

Figure 5. Impact of chemogenetic excitation of distinct PL projections on behavior. $\boldsymbol{A}$, Projection-specific chemogenetic approach involving a Cre-dependent Vector 1 (AAV8-hSyn-DI0-hM3Dq(mCherry) or AAV8-hSyn-DI0-mCherry) infused into the $\mathrm{PL}$, and AAV2retro-hSyn-Cre(GFP) was infused into the BLA, NAC, or VTA. $\boldsymbol{B}$, Cre-dependent mCherry expression in the PL of a C57BL/6J mouse treated with intra-PL AAV8-hSyn-DI0-mCherry and intra-BLA AAV2retro-hSyn-Cre(GFP). Scale bar, $325 \mu \mathrm{m}$. C, Trace fear conditioning in male C57BL/6J mice treated with intra-PL DI0-hM3Dq(mCherry) or control vector, and intra-BLA AAV2retro-Cre(GFP). Percent freezing observed during the cue recall test, conducted $2 \mathrm{~d}$ after trace fear conditioning in the presence of CNO (2 mg/kg, i.p.) (unpaired Student's $t$ test; $N=8-11$ mice/group). D, Saline- and acute cocaine-induced (15 mg/kg, i.p.) motor activity in male C57BL/6J mice treated with intra-PL DI0-hM3Dq(mCherry) or control vector, and intra-BLA AAV2retro-Cre(GFP), measured $30 \mathrm{~min}$ after CNO administration $(2 \mathrm{mg} / \mathrm{kg}$, i.p.). $* * * * p<0.0001$ (two-way repeated-measures ANOVA with Bonferroni's post hoc test). $N=8-11$ mice/group. $\boldsymbol{E}$, Cre-dependent mCherry expression in the PL of a C57BL/6J mouse treated with intra-PL AAV8-hSyn-DI0-mCherry and intra-NAc AAV2retro-hSyn-Cre(GFP). Scale bar, $325 \mu \mathrm{m}$. $\boldsymbol{F}$, Trace fear conditioning in male C57BL/6J mice treated with intra-PL DI0-hM3Dq(mCherry) or control vector, and intra-NAc AAV2retro-Cre(GFP). Percent freezing observed during the cue recall test, conducted $2 \mathrm{~d}$ after trace fear conditioning in the presence of CNO (2 mg/kg, i.p.) (unpaired Student's $t$ test; $N=9-11$ mice/group). $G$, Saline- and acute cocaine-induced ( $15 \mathrm{mg} / \mathrm{kg}$, i.p.) motor activity in male $(57 \mathrm{BL} / 6 \mathrm{~J}$ mice treated with intra-PL DI0-hM3Dq(mCherry) or control vector, and intra-NAC AAV2retro-Cre(GFP), measured $30 \mathrm{~min}$ after CNO administration (2 mg/kg, i.p.) (two-way repeatedmeasures ANOVA; $N=9-11$ mice/group). $\boldsymbol{H}$, Cre-dependent mCherry expression in the PL of a $(57 \mathrm{BL} / 6 \mathrm{~J}$ mouse treated with intra-PL AAV8-hSyn-DI0-mCherry and intra-VTA AAV2retro-hSyn-Cre(GFP). Scale bar, $325 \mu \mathrm{m}$. I, Trace fear conditioning in male C57BL/6J mice treated with intra-PL DI0-hM3Dq(mCherry) or control vector, and intra-VTA AAV2retro-Cre(GFP). Percent freezing observed during the cue recall test, conducted $2 \mathrm{~d}$ after trace fear conditioning in the presence of CNO ( $2 \mathrm{mg} / \mathrm{kg}$, i.p.). $* p<0.05$ (unpaired Student's $t$ test). $N=10$ or 11 mice/group. J, Saline- and acute cocaine-induced (15 mg/kg, i.p.) motor activity in male $\mathrm{C} 57 \mathrm{BL} / 6 \mathrm{~J}$ mice treated with intra-PL DI0-hM3Dq(mCherry) or control vector, and intra-VTA AAV2retroCre(GFP), measured 30 min after systemic CNO administration ( $2 \mathrm{mg} / \mathrm{kg}$, i.p.). ${ }^{\# \#} p<0.001$ (main effect of viral treatment). $N=10$ or 11 mice/group.

cocaine-induced locomotor sensitization (Pierce et al., 1998; Tzschentke and Schmidt, 1998, 2000), and baclofen infusion into the mPFC blocked acute cocaine-induced locomotion and induction of locomotor sensitization without affecting basal activity (Steketee and Beyer, 2005; Riaz et al., 2019). Collectively, these lines of evidence suggest that the cocaineinduced suppression of GIRK-dependent signaling in PL pyramidal neurons contributes to locomotor sensitization.

The mPFC regulates cognitive functions (Gilmartin et al., 2014; Giustino and Maren, 2015), including trace fear learning (Runyan et al., 2004; Gilmartin and Helmstetter, 2010; Gilmartin et al., 2013). Persistent firing in the PL during the trace interval is critical for trace fear learning (Fuster, 1973; Funahashi et al., 1989; Baeg et al., 2001; Compte et al., 2003; Han et al., 2003; Runyan et al., 2004; Gilmartin and McEchron, 2005; Blum et al., 2006; Gilmartin and Helmstetter, 2010; Gilmartin et al., 2013), and optogenetic silencing of the PL, either throughout the conditioning session or during the trace interval, precludes fear learning (Gilmartin et al., 2013). Our chemogenetic data show that acute excitation of PL pyramidal neurons during conditioning can also disrupt fear learning. Disruptions in trace fear learning during conditioning may reflect impairments in attention and/or working memory (Gilmartin et al., 2014), processes that are altered by psychostimulant exposure in humans (Simon et al., 2002; Lundqvist, 2005; Gould, 2010), nonhuman primates (Porter et al., 2011), and rodents (Briand et al., 2008; George et al., 2008). Alternatively, our chemogenetic manipulations, which likely impacted PL pyramidal neuron excitability during and shortly after conditioning, may also have disrupted memory consolidation (Rizzo et al., 2017).

Prolonged exposure to cocaine persistently elevates PL pyramidal neuron excitability (Dong et al., 2005; Nasif et al., 2005; Hearing et al., 2013; Otis et al., 2018; Sepulveda-Orengo et al., 2018) and reduces GABAergic neurotransmission in these neurons (Huang et al., 2007; Hearing et al., 2013; Slaker et al., 2015). To mimic these adaptations in drug-naive mice, we used three distinct approaches: viral Cre ablation of GIRK channels, chemogenetic excitation of PL pyramidal neurons, and chemogenetic inhibition of PL GABA neurons. While 
viral Cre ablation of GIRK channel activity in PL pyramidal neurons did not impact saline-induced motor activity, direct or indirect chemogenetic excitation of PL pyramidal neurons did. The outcomes were surprising given prior reports that chemogenetic excitation of PL pyramidal neurons did not alter open-field activity (Warthen et al., 2016; Pati et al., 2018). These differences may relate to the scope of viral targeting, test duration, and/or behavioral testing history of subjects used (McIlwain et al., 2001). In line with our results, disinhibiting PL neurons by antagonizing $\mathrm{GABA}_{\mathrm{A}} \mathrm{Rs}$ or blocking GABA synthesis increased locomotion in $30 \mathrm{~min}$ open-field tests (Enomoto et al., 2011; Asinof and Paine, 2013). Notably, neither of our chemogenetic manipulations, designed to model chronic cocaine-induced plasticity, occluded the acute motor-stimulatory effect of cocaine. Thus, acute cocaine exposure and acute PL pyramidal neuron excitation likely work through distinct/additive mechanisms to augment locomotion.

Chemogenetic excitation in PL pyramidal neurons enhanced key measures of neuronal excitability (rheobase and RMP), enhanced motor activity measured after saline or cocaine injection, and disrupted trace fear learning. In contrast, GIRK ablation increased PL pyramidal neuron excitability (rheobase but not RMP), enhanced cocaine-induced but not baseline activity, and evoked a nonsignificant decrease in trace fear learning. Why do persistent (GIRK ablation) and acute (chemogenetic) manipulations targeting PL pyramidal neurons yield overlapping but distinct behavioral outcomes? We speculate that ablation of GIRK channels, predominantly located in the somatodendritic compartment (Luscher et al., 1997; Koyrakh et al., 2005), preferentially impact somatodendritic physiology of PL pyramidal neurons, whereas chemogenetic excitation exerts a multifaceted influence on intracellular signaling in somatodendritic/postsynaptic and axonal/presynaptic compartments (Smith et al., 2016). Moreover, the persistent suppression of GIRK channel activity may promote compensatory adaptations not seen in acute chemogenetic models.

For our projection-specific manipulations, we targeted brain regions that receive glutamatergic input from the PL and regulate fear learning and/or motor activity (Fig. 6). The NAc has been implicated in fear learning (Wendler et al., 2014) and the acute motor-stimulatory effect of cocaine (Ito et al., 2004), and mPFC inputs are involved in the development and expression of locomotor sensitization (Steketee and Kalivas, 2011). Nevertheless, we did not see any impact of exciting NAc-projecting PL pyramidal neurons on fear learning, or motor activity. Consistent with the latter finding, optogenetic stimulation of dorsal mPFC-toNAc projections did not alter movement velocity in mice (Otis et al., 2017). Similarly, despite evidence that activity in the PL and BLA is necessary for trace fear learning (Gilmartin et al., 2013; Kochli et al., 2015; Kirry et al., 2020), we found that exciting BLA-projecting PL pyramidal neurons was without effect. This result is consistent with a study showing that optogenetic excitation of dorsal mPFC-amygdala projections did not affect cue fear learning in a delay fear conditioning model (Adhikari et al., 2015). Interestingly, while exciting BLA-projecting PL pyramidal neurons did not affect basal locomotion, in line with similar reports (Adhikari et al., 2015; Murugan et al., 2017), this manipulation suppressed cocaine-induced activity. Taking into account previous reports showing that reversible inactivation of the BLA enhanced hyperactivity evoked by either cocaine (Herzig and Schmidt, 2007) or amphetamine (Woods and Ettenberg, 2004; Degoulet et al., 2009), our findings suggest that BLA neuron excitability is negatively correlated with cocaine-induced motor activity and subject to modulation via PL glutamate.

The VTA plays a significant role in motor activity and locomotor sensitization (Steketee and Kalivas, 2011; Runegaard et al., 2019). Chemogenetic inhibition of VTA DA neurons reduced basal and cocaine-induced locomotion (Runegaard et al., 2018), while exciting VTA DA neurons, or the VTA-to-NAc projection, elevated basal locomotion (Boekhoudt et al., 2016; Runegaard et al., 2018; Jing et al., 2019; Mahler et al., 2019; Runegaard et al., 2019). mPFC pyramidal neurons synapse onto VTA DA neurons (Carr and Sesack, 2000; Sesack et al., 2003; Geisler and Wise, 2008) and activation of the mPFC (Murase et al., 1993; Tong et al., 1996) or intra-VTA infusion of glutamatergic agonists (Johnson et al., 1992; Chergui et al., 1993) induces burst-spiking of VTA DA neurons in vivo. mPFC stimulation also enhances DA release in the NAc (Murase et al., 1993; Taber and Fibiger, 1995; Karreman and Moghaddam, 1996), suggesting that exciting the PL projection to the VTA directly activates the mesolimbic DA pathway. Indeed, an excitatory monosynaptic projection from the mPFC to NAc-projecting VTA DA neurons has been reported (Beier et al., 2015). VTA-projecting mPFC neurons exhibit cocaine-induced plasticity that facilitates glutamate release in the VTA and contributes to addictive behaviors, including behavioral sensitization (Steketee and Kalivas, 2011; Hearing et al., 2013). We report here that acute stimulation of PL projections to the VTA enhances motor activity measured following saline or cocaine injection. The VTA also regulates aversive learning (Abraham et al., 2014), and optogenetic inhibition of VTA DA neurons during footshock (but not auditory cue) presentation enhanced cue fear recall (Luo et al., 2018). We show that acute excitation of VTA-projecting PL pyramidal neurons during trace fear conditioning disrupts cue fear recall. As the PL-to-VTA projection is subject to cocaine-induced plasticity (Hearing et al., 2013), it is tempting to speculate that some of the dysregulation of learning/memory processes seen following chronic cocaine exposure is linked in part to enhanced excitability of VTA-projecting PL pyramidal neurons (Goldstein and Volkow, 2011). 
In conclusion, we show that distinct manipulations of PL pyramidal neuron excitability in drug-naive mice exert overlapping but distinct consequences on behaviors relevant to addiction. Our work further suggests that enhanced excitability of the glutamatergic PL projection to the VTA presensitizes mice to the motor-stimulatory effect of cocaine and disrupts associative fear learning. As such, interventions that suppress the excitability of this microcircuit may prove useful for suppressing problematic behaviors linked to chronic cocaine intake.

\section{References}

Abraham AD, Neve KA, Lattal KM (2014) Dopamine and extinction: a convergence of theory with fear and reward circuitry. Neurobiol Learn Mem 108:65-77.

Adhikari A, Lerner TN, Finkelstein J, Pak S, Jennings JH, Davidson TJ, Ferenczi E, Gunaydin LA, Mirzabekov JJ, Ye L, Kim SY, Lei A, Deisseroth K (2015) Basomedial amygdala mediates top-down control of anxiety and fear. Nature 527:179-185.

Asinof SK, Paine TA (2013) Inhibition of GABA synthesis in the prefrontal cortex increases locomotor activity but does not affect attention in the 5choice serial reaction time task. Neuropharmacology 65:39-47.

Baeg EH, Kim YB, Jang J, Kim HT, Mook-Jung I, Jung MW (2001) Fast spiking and regular spiking neural correlates of fear conditioning in the medial prefrontal cortex of the rat. Cereb Cortex 11:441-451.

Beier KT, Steinberg EE, DeLoach KE, Xie S, Miyamichi K, Schwarz L, Gao XJ, Kremer EJ, Malenka RC, Luo L (2015) Circuit architecture of VTA dopamine neurons revealed by systematic input-output mapping. Cell 162:622-634.

Bettahi I, Marker CL, Roman MI, Wickman K (2002) Contribution of the Kir3.1 subunit to the muscarinic-gated atrial potassium channel $\mathrm{I}_{\mathrm{KACh}} \mathrm{J}$ Biol Chem 277:48282-48288.

Blum S, Hebert AE, Dash PK (2006) A role for the prefrontal cortex in recall of recent and remote memories. Neuroreport 17:341-344.

Boekhoudt L, Omrani A, Luijendijk MC, Wolterink-Donselaar IG, Wijbrans EC, van der Plasse G, Adan RA (2016) Chemogenetic activation of dopamine neurons in the ventral tegmental area, but not substantia nigra, induces hyperactivity in rats. Eur Neuropsychopharmacol 26:1784-1793.

Briand LA, Flagel SB, Garcia-Fuster MJ, Watson SJ, Akil H, Sarter M, Robinson TE (2008) Persistent alterations in cognitive function and prefrontal dopamine D2 receptors following extended, but not limited, access to self-administered cocaine. Neuropsychopharmacology 33:29692980.

Brinley-Reed M, Mascagni F, McDonald AJ (1995) Synaptology of prefrontal cortical projections to the basolateral amygdala: an electron microscopic study in the rat. Neurosci Lett 202:45-48.

Campanac E, Hoffman DA (2013) Repeated cocaine exposure increases fastspiking interneuron excitability in the rat medial prefrontal cortex. J Neurophysiol 109:2781-2792.

Carr DB, Sesack SR (2000) Projections from the rat prefrontal cortex to the ventral tegmental area: target specificity in the synaptic associations with mesoaccumbens and mesocortical neurons. J Neurosci 20:3864-3873.

Chergui K, Charlety PJ, Akaoka H, Saunier CF, Brunet JL, Buda M, Svensson TH, Chouvet G (1993) Tonic activation of NMDA receptors causes spontaneous burst discharge of rat midbrain dopamine neurons in vivo. Eur J Neurosci 5:137-144.

Compte A, Constantinidis C, Tegner J, Raghavachari S, Chafee MV, Goldman-Rakic PS, Wang XJ (2003) Temporally irregular mnemonic persistent activity in prefrontal neurons of monkeys during a delayed response task. J Neurophysiol 90:3441-3454.

Degoulet MF, Rostain JC, David HN, Abraini JH (2009) Repeated administration of amphetamine induces a shift of the prefrontal cortex and basolateral amygdala motor function. Int J Neuropsychopharmacol 12:965974.

Dimidschstein J, Chen Q, Tremblay R, Rogers SL, Saldi GA, Guo L, Xu Q, Liu R, Lu C, Chu J, Grimley JS, Krostag AR, Kaykas A, Avery MC, Rashid MS, Baek M, Jacob AL, Smith GB, Wilson DE, Kosche G, et al. (2016) A viral strategy for targeting and manipulating interneurons across vertebrate species. Nat Neurosci 19:1743-1749.

Dong Y, Nasif FJ, Tsui JJ, Ju WY, Cooper DC, Hu XT, Malenka RC, White FJ (2005) Cocaine-induced plasticity of intrinsic membrane properties in prefrontal cortex pyramidal neurons: adaptations in potassium currents. J Neurosci 25:936-940.

Enomoto T, Tse MT, Floresco SB (2011) Reducing prefrontal gamma-aminobutyric acid activity induces cognitive, behavioral, and dopaminergic abnormalities that resemble schizophrenia. Biol Psychiatry 69:432-441.

Ferguson BR, Gao WJ (2018) Thalamic control of cognition and social behavior via regulation of gamma-aminobutyric acidergic signaling and excitation/inhibition balance in the medial prefrontal cortex. Biol Psychiatry 83:657-669.

Funahashi S, Bruce CJ, Goldman-Rakic PS (1989) Mnemonic coding of visual space in the monkey's dorsolateral prefrontal cortex. J Neurophysiol 61:331-349.

Fuster JM (1973) Unit activity in prefrontal cortex during delayed-response performance: neuronal correlates of transient memory. J Neurophysiol 36:61-78.

Gass JT, Chandler LJ (2013) The plasticity of extinction: contribution of the prefrontal cortex in treating addiction through inhibitory learning. Front Psychiatry 4:46.

Geisler S, Wise RA (2008) Functional implications of glutamatergic projections to the ventral tegmental area. Rev Neurosci 19:227-244.

George O, Mandyam CD, Wee S, Koob GF (2008) Extended access to cocaine self-administration produces long-lasting prefrontal cortex-dependent working memory impairments. Neuropsychopharmacology 33:24742482.

Gilmartin MR, McEchron MD (2005) Single neurons in the medial prefrontal cortex of the rat exhibit tonic and phasic coding during trace fear conditioning. Behav Neurosci 119:1496-1510.

Gilmartin MR, Helmstetter FJ (2010) Trace and contextual fear conditioning require neural activity and NMDA receptor-dependent transmission in the medial prefrontal cortex. Learn Mem 17:289-296.

Gilmartin MR, Miyawaki H, Helmstetter FJ, Diba K (2013) Prefrontal activity links nonoverlapping events in memory. J Neurosci 33:10910-10914.

Gilmartin MR, Balderston NL, Helmstetter FJ (2014) Prefrontal cortical regulation of fear learning. Trends Neurosci 37:455-464.

Giustino TF, Maren S (2015) The role of the medial prefrontal cortex in the conditioning and extinction of fear. Front Behav Neurosci 9:298.

Goldstein RZ, Volkow ND (2011) Dysfunction of the prefrontal cortex in addiction: neuroimaging findings and clinical implications. Nat Rev Neurosci 12:652-669.

Gould TJ (2010) Addiction and cognition. Addict Sci Clin Pract 5:4-14.

Gourley SL, Taylor JR (2016) Going and stopping: dichotomies in behavioral control by the prefrontal cortex. Nat Neurosci 19:656-664.

Han CJ, O’Tuathaigh CM, van Trigt L, Quinn JJ, Fanselow MS, Mongeau R, Koch C, Anderson DJ (2003) Trace but not delay fear conditioning requires attention and the anterior cingulate cortex. Proc Natl Acad Sci USA 100:13087-13092.

Hearing M, Kotecki L, Marron Fernandez de Velasco E, Fajardo-Serrano A, Chung HJ, Luján R, Wickman K (2013) Repeated cocaine weakens GABA(B)-GIRK signaling in layer 5/6 pyramidal neurons in the prelimbic cortex. Neuron 80:159-170.

Herzig V, Schmidt WJ (2007) Amygdala cannulation alters expression of cocaine conditioned place preference and locomotion in rats. Addict Biol $12: 478-481$

Huang CC, Lin HJ, Hsu KS (2007) Repeated cocaine administration promotes long-term potentiation induction in rat medial prefrontal cortex. Cereb Cortex 17:1877-1888.

Ito R, Robbins TW, Everitt BJ (2004) Differential control over cocaine-seeking behavior by nucleus accumbens core and shell. Nat Neurosci 7:389397.

Jasinska AJ, Chen BT, Bonci A, Stein EA (2015) Dorsal medial prefrontal cortex (MPFC) circuitry in rodent models of cocaine use: implications for drug addiction therapies. Addict Biol 20:215-226.

Jing MY, Han X, Zhao TY, Wang ZY, Lu GY, Wu N, Song R, Li J (2019) Reexamining the role of ventral tegmental area dopaminergic neurons in motor activity and reinforcement by chemogenetic and optogenetic manipulation in mice. Metab Brain Dis 34:1421-1430.

Jo YS, Lee J, Mizumori SJ (2013) Effects of prefrontal cortical inactivation on neural activity in the ventral tegmental area. J Neurosci 33:8159-8171.

Johnson SW, Seutin V, North RA (1992) Burst firing in dopamine neurons induced by N-methyl-D-aspartate: role of electrogenic sodium pump. Science 258:665-667. 
Kalivas PW (2009) The glutamate homeostasis hypothesis of addiction. Nat Rev Neurosci 10:561-572.

Karreman M, Moghaddam B (1996) The prefrontal cortex regulates the basal release of dopamine in the limbic striatum: an effect mediated by ventral tegmental area. J Neurochem 66:589-598.

Kawaguchi Y (1993) Groupings of nonpyramidal and pyramidal cells with specific physiological and morphological characteristics in rat frontal cortex. J Neurophysiol 69:416-431.

Kirry AJ, Twining RC, Gilmartin MR (2020) Prelimbic input to basolateral amygdala facilitates the acquisition of trace cued fear memory under weak training conditions. Neurobiol Learn Mem 172:107249.

Kochli DE, Thompson EC, Fricke EA, Postle AF, Quinn JJ (2015) The amygdala is critical for trace, delay, and contextual fear conditioning. Learn Mem 22:92-100.

Koyrakh L, Lujan R, Colon J, Karschin C, Kurachi Y, Karschin A, Wickman K (2005) Molecular and cellular diversity of neuronal G-protein-gated potassium channels. J Neurosci 25:11468-11478.

Kvitsiani D, Ranade S, Hangya B, Taniguchi H, Huang JZ, Kepecs A (2013) Distinct behavioural and network correlates of two interneuron types in prefrontal cortex. Nature 498:363-366.

Lein ES, Hawrylycz MJ, Ao N, Ayres M, Bensinger A, Bernard A, Boe AF, Boguski MS, Brockway KS, Byrnes EJ, Chen L, Chen L, Chen TM, Chin MC, Chong J, Crook BE, Czaplinska A, Dang CN, Datta S, Dee NR, et al. (2007) Genome-wide atlas of gene expression in the adult mouse brain. Nature 445:168-176.

Li Y, Hu XT, Berney TG, Vartanian AJ, Stine CD, Wolf ME, White FJ (1999) Both glutamate receptor antagonists and prefrontal cortex lesions prevent induction of cocaine sensitization and associated neuroadaptations. Synapse 34:169-180.

Lu H, Cheng PL, Lim BK, Khoshnevisrad N, Poo MM (2010) Elevated BDNF after cocaine withdrawal facilitates LTP in medial prefrontal cortex by suppressing GABA inhibition. Neuron 67:821-833.

Lundqvist T (2005) Cognitive consequences of cannabis use: comparison with abuse of stimulants and heroin with regard to attention, memory and executive functions. Pharmacol Biochem Behav 81:319-330.

Luo R, Uematsu A, Weitemier A, Aquili L, Koivumaa J, McHugh TJ, Johansen JP (2018) A dopaminergic switch for fear to safety transitions. Nat Commun 9:2483.

Luscher C, Jan LY, Stoffel M, Malenka RC, Nicoll RA (1997) G proteincoupled inwardly rectifying $\mathrm{K}^{+}$channels (GIRKs) mediate postsynaptic but not presynaptic transmitter actions in hippocampal neurons. Neuron 19:687-695.

Mahler SV, Brodnik ZD, Cox BM, Buchta WC, Bentzley BS, Quintanilla J, Cope ZA, Lin EC, Riedy MD, Scofield MD, Messinger J, Ruiz CM, Riegel AC, Espana RA, Aston-Jones G (2019) Chemogenetic manipulations of ventral tegmental area dopamine neurons reveal multifaceted roles in cocaine abuse. J Neurosci 39:503-518.

Marrotn Fernandez de Velasco E, Hearing M, Xia Z, Victoria NC, Luján R, Wickman K (2015) Sex differences in GABA(B)R-GIRK signaling in layer $5 / 6$ pyramidal neurons of the mouse prelimbic cortex. Neuropharmacology 95:353-360.

Marron Fernandez de Velasco E, Carlblom N, Xia Z, Wickman K (2017) Suppression of inhibitory $G$ protein signaling in forebrain pyramidal neurons triggers plasticity of glutamatergic neurotransmission in the nucleus accumbens core. Neuropharmacology 117:33-40.

McFarland K, Kalivas PW (2001) The circuitry mediating cocaine-induced reinstatement of drug-seeking behavior. J Neurosci 21:8655-8663.

McFarland K, Lapish CC, Kalivas PW (2003) Prefrontal glutamate release into the core of the nucleus accumbens mediates cocaine-induced reinstatement of drug-seeking behavior. J Neurosci 23:3531-3537.

Mcllwain KL, Merriweather MY, Yuva-Paylor LA, Paylor R (2001) The use of behavioral test batteries: effects of training history. Physiol Behav 73:705-717.

Moorman DE, James MH, McGlinchey EM, Aston-Jones G (2015) Differential roles of medial prefrontal subregions in the regulation of drug seeking. Brain Res 1628:130-146.

Murase S, Grenhoff J, Chouvet G, Gonon FG, Svensson TH (1993) Prefrontal cortex regulates burst firing and transmitter release in rat mesolimbic dopamine neurons studied in vivo. Neurosci Lett 157:53-56.

Murugan M, Jang HJ, Park M, Miller EM, Cox J, Taliaferro JP, Parker NF, Bhave V, Hur H, Liang Y, Nectow AR, Pillow JW, Witten IB (2017)
Combined social and spatial coding in a descending projection from the prefrontal cortex. Cell 171:1663-1677.e1616.

Nasif FJ, Sidiropoulou K, Hu XT, White FJ (2005) Repeated cocaine administration increases membrane excitability of pyramidal neurons in the rat medial prefrontal cortex. J Pharmacol Exp Ther 312:1305-1313.

Nasif FJ, Hu XT, Ramirez OA, Perez MF (2011) Inhibition of neuronal nitric oxide synthase prevents alterations in medial prefrontal cortex excitability induced by repeated cocaine administration. Psychopharmacology (Berl) 218:323-330.

Otis JM, Namboodiri VM, Matan AM, Voets ES, Mohorn EP, Kosyk O, McHenry JA, Robinson JE, Resendez SL, Rossi MA, Stuber GD (2017) Prefrontal cortex output circuits guide reward seeking through divergent cue encoding. Nature 543:103-107.

Otis JM, Fitzgerald MK, Yousuf H, Burkard JL, Drake M, Mueller D (2018) Prefrontal neuronal excitability maintains cocaine-associated memory during retrieval. Front Behav Neurosci 12:119.

Padgett CL, Lalive AL, Tan KR, Terunuma M, Munoz MB, Pangalos MN, Martínez-Hernández J, Watanabe M, Moss SJ, Luján R, Lüscher C, Slesinger PA (2012) Methamphetamine-evoked depression of GABA(B) receptor signaling in GABA neurons of the VTA. Neuron 73:978-989.

Pati S, Sood A, Mukhopadhyay S, Vaidya VA (2018) Acute pharmacogenetic activation of medial prefrontal cortex excitatory neurons regulates anxiety-like behaviour. J Biosci 43:85-95.

Peters J, Kalivas PW, Quirk GJ (2009) Extinction circuits for fear and addiction overlap in prefrontal cortex. Learn Mem 16:279-288.

Pierce RC, Reeder DC, Hicks J, Morgan ZR, Kalivas PW (1998) Ibotenic acid lesions of the dorsal prefrontal cortex disrupt the expression of behavioral sensitization to cocaine. Neuroscience 82:1103-1114.

Porter JN, Olsen AS, Gurnsey K, Dugan BP, Jedema HP, Bradberry CW (2011) Chronic cocaine self-administration in rhesus monkeys: impact on associative learning, cognitive control, and working memory. J Neurosci 31:4926-4934.

Riaz S, Puveendrakumaran P, Khan D, Yoon S, Hamel L, Ito R (2019) Prelimbic and infralimbic cortical inactivations attenuate contextually driven discriminative responding for reward. Sci Rep 9:3982.

Rizzo V, Touzani K, Raveendra BL, Swarnkar S, Lora J, Kadakkuzha BM, Liu XA, Zhang C, Betel D, Stackman RW, Puthanveettil SV (2017) Encoding of contextual fear memory requires de novo proteins in the prelimbic cortex. Biol Psychiatry Cogn Neurosci Neuroimaging 2:158-169.

Runegaard AH, Sorensen AT, Fitzpatrick CM, Jorgensen SH, Petersen AV, Hansen NW, Weikop P, Andreasen JT, Mikkelsen JD, Perrier JF, Woldbye D, Rickhag M, Wortwein G, Gether U (2018) Locomotor- and reward-enhancing effects of cocaine are differentially regulated by chemogenetic stimulation of Gi-signaling in dopaminergic neurons. eNeuro 5:ENEURO.0345-17.2018.

Runegaard AH, Fitzpatrick CM, Woldbye DP, Andreasen JT, Sorensen AT, Gether U (2019) Modulating dopamine signaling and behavior with chemogenetics: concepts, progress, and challenges. Pharmacol Rev 71:123156.

Runyan JD, Moore AN, Dash PK (2004) A role for prefrontal cortex in memory storage for trace fear conditioning. J Neurosci 24:1288-1295.

Schneider CA, Rasband WS, Eliceiri KW (2012) NIH Image to ImageJ: 25 years of image analysis. Nat Methods 9:671-675.

Sepulveda-Orengo MT, Healey KL, Kim R, Auriemma AC, Rojas J, Woronoff N, Hyppolite R, Reissner KJ (2018) Riluzole impairs cocaine reinstatement and restores adaptations in intrinsic excitability and GLT-1 expression. Neuropsychopharmacology 43:1212-1223.

Sesack SR, Pickel VM (1992) Prefrontal cortical efferents in the rat synapse on unlabeled neuronal targets of catecholamine terminals in the nucleus accumbens septi and on dopamine neurons in the ventral tegmental area. J Comp Neurol 320:145-160.

Sesack SR, Deutch AY, Roth RH, Bunney BS (1989) Topographical organization of the efferent projections of the medial prefrontal cortex in the rat: an anterograde tract-tracing study with Phaseolus vulgaris leucoagglutinin. J Comp Neurol 290:213-242.

Sesack SR, Carr DB, Omelchenko N, Pinto A (2003) Anatomical substrates for glutamate-dopamine interactions: evidence for specificity of connections and extrasynaptic actions. Ann NY Acad Sci 1003:36-52.

Signorini S, Liao YJ, Duncan SA, Jan LY, Stoffel M (1997) Normal cerebellar development but susceptibility to seizures in mice lacking G proteincoupled, inwardly rectifying $\mathrm{K}^{+}$channel GIRK2. Proc Natl Acad Sci USA 94:923-927. 
Simon SL, Domier CP, Sim T, Richardson K, Rawson RA, Ling W (2002) Cognitive performance of current methamphetamine and cocaine abusers. J Addict Dis 21:61-74.

Slaker M, Churchill L, Todd RP, Blacktop JM, Zuloaga DG, Raber J, Darling RA, Brown TE, Sorg BA (2015) Removal of perineuronal nets in the medial prefrontal cortex impairs the acquisition and reconsolidation of a cocaine-induced conditioned place preference memory. J Neurosci 35:4190-4202.

Slaker ML, Jorgensen ET, Hegarty DM, Liu X, Kong Y, Zhang F, Linhardt RJ, Brown TE, Aicher SA, Sorg BA (2018) Cocaine exposure modulates perineuronal bets and synaptic excitability of fast-spiking interneurons in the medial prefrontal cortex. eNeuro 5:ENEURO.0221-18.2018.

Smith KS, Bucci DJ, Luikart BW, Mahler SV (2016) DREADDS: use and application in behavioral neuroscience. Behav Neurosci 130:137-155.

Steketee JD (2003) Neurotransmitter systems of the medial prefrontal cortex: potential role in sensitization to psychostimulants. Brain Res Brain Res Rev 41:203-228.

Steketee JD, Beyer CE (2005) Injections of baclofen into the ventral medial prefrontal cortex block the initiation, but not the expression, of cocaine sensitization in rats. Psychopharmacology (Berl) 180:352-358.

Steketee JD, Kalivas PW (2011) Drug wanting: behavioral sensitization and relapse to drug-seeking behavior. Pharmacol Rev 63:348-365.

Taber MT, Fibiger HC (1995) Electrical stimulation of the prefrontal cortex increases dopamine release in the nucleus accumbens of the rat: modulation by metabotropic glutamate receptors. J Neurosci 15:3896-3904.

Tamamaki N, Yanagawa Y, Tomioka R, Miyazaki J, Obata K, Kaneko T (2003) Green fluorescent protein expression and colocalization with calretinin, parvalbumin, and somatostatin in the GAD67-GFP knock-in mouse. J Comp Neurol 467:60-79.

Tervo DG, Hwang BY, Viswanathan S, Gaj T, Lavzin M, Ritola KD, Lindo S, Michael S, Kuleshova E, Ojala D, Huang CC, Gerfen CR, Schiller J, Dudman JT, Hantman AW, Looger LL, Schaffer DV, Karpova AY (2016) A designer AAV variant permits efficient retrograde access to projection neurons. Neuron 92:372-382.

Tipps M, Marron Fernandez de Velasco E, Schaeffer A, Wickman K (2018) Inhibition of pyramidal neurons in the basal amygdala promotes fear learning. eNeuro 5:ENEURO.0272-18.2018.

Tong ZY, Overton PG, Clark D (1996) Stimulation of the prefrontal cortex in the rat induces patterns of activity in midbrain dopaminergic neurons which resemble natural burst events. Synapse 22:195-208.
Torrecilla M, Marker CL, Cintora SC, Stoffel M, Williams JT, Wickman K (2002) G-protein-gated potassium channels containing Kir3.2 and Kir3.3 subunits mediate the acute inhibitory effects of opioids on locus ceruleus neurons. J Neurosci 22:4328-4334.

Tzschentke TM, Schmidt WJ (1998) The development of cocaine-induced behavioral sensitization is affected by discrete quinolinic acid lesions of the prelimbic medial prefrontal cortex. Brain Res 795:71-76.

Tzschentke TM, Schmidt WJ (2000) Differential effects of discrete subareaspecific lesions of the rat medial prefrontal cortex on amphetamine- and cocaine-induced behavioural sensitization. Cereb Cortex 10:488-498.

Vertes RP (2004) Differential projections of the infralimbic and prelimbic cortex in the rat. Synapse 51:32-58.

Volle J, Yu X, Sun H, Tanninen SE, Insel N, Takehara-Nishiuchi K (2016) Enhancing prefrontal neuron activity enables associative learning of temporally disparate events. Cell Rep 15:2400-2410.

Warthen DM, Lambeth PS, Ottolini M, Shi Y, Barker BS, Gaykema RP, Newmyer BA, Joy-Gaba J, Ohmura Y, Perez-Reyes E, Güler AD, Patel MK, Scott MM (2016) Activation of pyramidal neurons in mouse medial prefrontal cortex enhances food-seeking behavior while reducing impulsivity in the absence of an effect on food intake. Front Behav Neurosci 10:63.

Wendler E, Gaspar JC, Ferreira TL, Barbiero JK, Andreatini R, Vital MA, Blaha CD, Winn P, Da Cunha C (2014) The roles of the nucleus accumbens core, dorsomedial striatum, and dorsolateral striatum in learning: performance and extinction of Pavlovian fear-conditioned responses and instrumental avoidance responses. Neurobiol Learn Mem 109:27-36.

Woods VE, Ettenberg A (2004) Increased amphetamine-induced locomotion during inactivation of the basolateral amygdala. Behav Brain Res 149:3339.

Woon EP, Sequeira MK, Barbee BR, Gourley SL (2020) Involvement of the rodent prelimbic and medial orbitofrontal cortices in goal-directed action: a brief review. J Neurosci Res 98:1020-1030.

Xu P, Chen A, Li Y, Xing X, Lu H (2019) Medial prefrontal cortex in neurological diseases. Physiol Genomics 51:432-442.

Zhang T, Yanagida J, Kamii H, Wada S, Domoto M, Sasase H, Deyama S, Takarada T, Hinoi E, Sakimura K, Yamanaka A, Maejima T, Mieda M, Sakurai T, Nishitani N, Nagayasu K, Kaneko S, Minami M, Kaneda K (2020) Glutamatergic neurons in the medial prefrontal cortex mediate the formation and retrieval of cocaine-associated memories in mice. Addict Biol 25:e12723. 